\title{
Differences of characteristics and performance with Bi3+ and Bi2O3 doping over TiO2 for photocatalytic oxidation under visible light
}

Article

Accepted Version

Huang, Q., Ye, J., Si, H., Yang, B., Tao, T., Zhao, Y., Chen, M. and Yang, H. (2020) Differences of characteristics and performance with $\mathrm{Bi} 3+$ and $\mathrm{Bi} 2 \mathrm{O} 3$ doping over $\mathrm{TiO} 2$ for photocatalytic oxidation under visible light. Catalysis Letters. pp. 1-13. ISSN 1011-372X doi: https://doi.org/10.1007/s10562019-03017-w Available at https://centaur.reading.ac.uk/87158/

It is advisable to refer to the publisher's version if you intend to cite from the work. See Guidance on citing.

To link to this article DOI: http://dx.doi.org/10.1007/s10562-019-03017-w

Publisher: Springer

All outputs in CentAUR are protected by Intellectual Property Rights law, including copyright law. Copyright and IPR is retained by the creators or other copyright holders. Terms and conditions for use of this material are defined in the End User Agreement. 


\section{CentAUR}

Central Archive at the University of Reading

Reading's research outputs online 
1 Differences of characteristics and performance with $\mathrm{Bi}^{3+}$ and $2 \quad \mathrm{Bi}_{2} \mathrm{O}_{3}$ doping over $\mathrm{TiO}_{2}$ for photocatalytic oxidation under

Qiong Huang ${ }^{1, *}$, Juan $\mathrm{Ye}^{1}$, Han $\mathrm{Si}^{1}$, Bo Yang ${ }^{1}$, Tao Tao ${ }^{1}$, Yunxia Zhao ${ }^{1}$, Mindong Chen ${ }^{1}$ and Hong Yang ${ }^{1,2, *}$

1 Jiangsu Collaborative Innovation Center of Atmospheric Environment and 9 Equipment Technologies, Jiangsu Key Laboratory of Atmospheric Environmental Monitoring \& Pollution Control, School of Environmental Science \& Engineering, Nanjing University of Information Science \& Technology, Nanjing 210044, China;

2 Department of Geography and Environmental Science, University of Reading,

Whiteknights, Reading, RG6 6AB, UK

*Corresponding author 1: Dr. Qiong Huang

School of Environmental Science and Engineering, Nanjing University of Information Science \& Technology, Nanjing 210044, China

Address: No. 219 Ningliu Road, Nanjing University of Information Science \& Technology, School of Environmental Science and Engineering, 210044, Nanjing, China

E-mail: hqhaixia@163.com (Q.H.)

$$
\text { Tel: }+862558731090 \quad \text { Fax: }+862558731090
$$

*Corresponding author 2: Dr. Hong Yang

Department of Geography and Environmental Science, University of Reading, Whiteknights, Reading, RG6 6AB, UK

E-mail: hongyanghy@gmail.com (H. Y.)

28 Tel: $+44(0) 1183787750$ 


\section{Differences of characteristics and performance with $\mathrm{Bi}^{3+}$ and}

$\mathrm{Bi}_{2} \mathrm{O}_{3}$ doping over $\mathrm{TiO}_{2}$ for photocatalytic oxidation under

\section{visible light}

Abstracts: Bi-doped $\mathrm{TiO}_{2}$ photocatalysts were synthesized by sol with a high-pressure hydrothermal method and developed for the photocatalytic degradation of formaldehyde under the visible light irradiation and ambient temperature. According to characterization, it could be found that some $\mathrm{Bi}$-doped $\mathrm{TiO}_{2}$ could be transformed into the distinctive crystals phase of $\mathrm{Bi}_{4} \mathrm{Ti}_{3} \mathrm{O}_{12}$, which was crucial for improving activity. The excess $\mathrm{Bi}_{2} \mathrm{O}_{3}$ doping into $\mathrm{TiO}_{2}$, such as $\mathrm{Bi}_{2} \mathrm{O}_{3}-\mathrm{N} / \mathrm{TiO}_{2}$ and $\mathrm{Bi}_{2} \mathrm{O}_{3}-\mathrm{C}_{7} \mathrm{TiO}_{2}$, generated a mixed oxides with $\mathrm{Bi}_{2} \mathrm{O}_{3}$ and $\mathrm{Bi}_{4} \mathrm{Ti}_{3} \mathrm{O}_{12}$, was not beneficial to increase the activity of HCHO oxidation, whereas $\mathrm{Bi}^{3+} / \mathrm{TiO}_{2}$ composed of $\mathrm{TiO}_{2}$ and $\mathrm{Bi}_{4} \mathrm{Ti}_{3} \mathrm{O}_{12}$ displayed a higher activity with good stability. It was worth noteworthy that $\mathrm{Bi}^{3+} / \mathrm{TiO}_{2}$ didn't show the lowest binding energy. However, it exhibited a lower PL intensity, higher adsorption, and activity due to the uniform particulates, high surface areas, and the strong interaction between $\mathrm{TiO}_{2}$ and $\mathrm{Bi}_{4} \mathrm{Ti}_{3} \mathrm{O}_{12}$, attributing to create superoxide radical anion $\left({ }^{\circ} \mathrm{O}_{2}{ }^{-}\right)$and hydroxyl radical $(\bullet \mathrm{OH})$. The present results of $\mathrm{Bi}^{3+} / \mathrm{TiO}_{2}$ indicated that $\mathrm{HCHO}$ could be effectively oxidized from 1.094 to $0.058 \mathrm{mg} / \mathrm{m}^{3}(94.7 \%)$ under visible light irradiation within $36 \mathrm{~h}$. The current research made effort to draw out the existing state of $\mathrm{Bi}$, which would be better, $\mathrm{Bi}^{3+}$ or $\mathrm{Bi}_{2} \mathrm{O}_{3}$, doped in the $\mathrm{TiO}_{2}$.

Keywords: $\mathrm{TiO}_{2}$; Bi-doped; Photocatalytic oxidation; Formaldehyde; Visible light 


\section{Introduction}

With the rapid development of economy and urbanization, decoration has turn into a kind of popular lifestyle. A large number of new decorative materials and furniture have been used in rooms, while they can release a variety of volatile organic compounds (VOCs), such as formaldehyde ${ }^{[1,2]}$, benzene ${ }^{[3,4]}$, toluene ${ }^{[5,6]}$ and so on ${ }^{[7]}$. Accordingly, indoor air pollution has become an increasingly serious problem. As people spend more time indoors than outdoors, people may suffer from a serious of greater impact on human health, including nausea, dizzy, headache, leukemia, and even cancer ${ }^{[8]}$. In particular, formaldehyde ( $\mathrm{HCHO})$, one of the notorious carcinogenic and deformitycausing substances identified by the World Health Organization (WHO), has been detected at elevated levels in various indoor environments ${ }^{[9]}$. Hence, seeking an effective method to remove indoor HCHO has been an urgent task. To date, the main strategies of eliminating HCHO include adsorption ${ }^{[10]}$, photocatalysis ${ }^{[11,12]}$, low temperature plasma ${ }^{[13]}$, and catalytic oxidation at ambient temperature ${ }^{[14]}$. Considering efficiency and practicality, photocatalytic oxidation using $\mathrm{TiO}_{2}$ semiconductors is one of advanced technologies and it is still receiving attentions from many researches ${ }^{[15,16]}$. Up to now, $\mathrm{TiO}_{2}$ is still the most frequently used photocatalyst due to the high solar sensitivity, chemical stability and low toxicity ${ }^{[17]}$. In addition, its high density of states in bands enables the efficient photo to current conversion, and this makes $\mathrm{TiO}_{2}$ more active than other semiconductors, such as $\mathrm{ZnO}, \mathrm{SnO}_{2}, \mathrm{ZrO}_{2}, \mathrm{CdS}$ and $\mathrm{g}_{-} \mathrm{C}_{3} \mathrm{~N}_{4}{ }^{[18]}$. Therefore, $\mathrm{TiO}_{2}$ has been widely applied in various photocatalytic fields, such as water and gas stream treatment, and organic contaminant decomposition ${ }^{[19,20]}$. However, owing to its large band gap energy of $3.2 \mathrm{eV}(\lambda<380 \mathrm{~nm}), \mathrm{TiO}_{2}$ absorbs only ultraviolet light rather than more visible light that including a large part of solar irradiation ${ }^{[21,22]}$. Furthermore, the overall quantum yield rate can be seriously impacted by the low electron transfer rate and a high recombination rate of photo-induced electrons and holes. In order to overcome those problems, lots of efforts have been made to adjust the properties of $\mathrm{TiO}_{2}$ with electronic, for example, the noble metal deposition ${ }^{[22]}$, the other semiconductor coupling [23], and metal cations or non-metal anions doping [24-27]. Coupling of $\mathrm{TiO}_{2}$ with $\mathrm{Bi}_{2} \mathrm{O}_{3}{ }^{[28]}$, as a promising semiconductor, has been found to be a 
good strategy for elongating the light region to the visible and enhancing the photocatalytic activity ${ }^{[29]}$. $\mathrm{Bi}_{2} \mathrm{O}_{3}$ is an excellent material for the photocatalytic oxidation due to its narrow band gap of $2.8 \mathrm{eV}$ and diversity in crystal structure with doping of $\mathrm{TiO}_{2}$. Some studies about the $\mathrm{Bi}_{2} \mathrm{O}_{3} / \mathrm{TiO}_{2}$ composite or $\mathrm{Bi}$-doped $\mathrm{TiO}_{2}$ found better performance of VOCs photocatalytic oxidation under the excitation of visible light ${ }^{[30]}$. However, it is still unclear about the existence state of bismuth to improve the oxidation activity over $\mathrm{Bi}$-doped $\mathrm{TiO}_{2}$, especially for $\mathrm{Bi}^{3+}$ or $\mathrm{Bi}_{2} \mathrm{O}_{3}$, which donate as composite oxides $\left(\mathrm{Bi}_{\mathrm{x}} \mathrm{TiO}_{\mathrm{y}}\right)$, or mixed oxides $\left(\mathrm{Bi}_{2} \mathrm{O}_{3}-\mathrm{TiO}_{2}\right)$, separately. Murcia-Lopez et al. ${ }^{[31]}$ synthesized a series of $\mathrm{Bi}^{3+}$-doped $\mathrm{TiO}_{2}$ catalysts with $2 \mathrm{wt} \%$ doping to evaluate the photocatalytic oxidation of phenol under UV-vis illumination and they found that the nominal content of $\mathrm{Bi}^{3+}$ in $\mathrm{TiO}_{2}$ was the main reason for the increase in the photocatalytic activity. Bentouami et al. ${ }^{[32]}$ also found that the binding energy of Bi detected by XPS wasn't the same as the one of $\mathrm{Bi}$ in $\mathrm{Bi}_{2} \mathrm{O}_{3}$, and the shift in binding energies of XPS could be ascribed to some valence states higher than $\mathrm{Bi}^{3+}$. Bouattour et al. ${ }^{[33]}$ and $\mathrm{Xu}$ et al. ${ }^{[34]}$ suggested that the doped Bi ions substitute some of the titanium atoms in the form of compound oxidation, such as $\mathrm{Ti}-\mathrm{O}-\mathrm{Bi}, \mathrm{Sr}_{1-\mathrm{x}} \mathrm{Bi}_{\mathrm{x}} \mathrm{Ti}_{1-\mathrm{x}} \mathrm{Fe}_{\mathrm{x}} \mathrm{O}_{3}$, and $\mathrm{BiFeO}_{3}$, according to the results of XRD and XPS. Kang et al ${ }^{[35]}$ found that $\mathrm{Bi}$ ions inserted into $\mathrm{TiO}_{2}$ could markedly improve $\mathrm{CO}_{2}$ reduction to $\mathrm{CH}_{4}$ due to the inhibited recombination of photogenerated electron-hole. However, some scholars had a different opinion that $\mathrm{Bi}_{2} \mathrm{O}_{3}$ rather than $\mathrm{Bi}^{3+}$ played an important role in the photocatalytic oxidation over Bi-doped $\mathrm{TiO}_{2}$. For instance, $\mathrm{Li}$ et al. ${ }^{[36]}$ found that the flower-like $\mathrm{Bi}_{2} \mathrm{O}_{3} / \mathrm{TiO}_{2}$ with enrichment $\mathrm{Bi}_{2} \mathrm{O}_{3}$ quantum dots on the surface of photocatalyst exhibited higher activity due to the strong interaction between $\mathrm{Bi}_{2} \mathrm{O}_{3}$ and $\mathrm{TiO}_{2}$. Leung ${ }^{[37]}$ and Wang ${ }^{[38]}$ et al. hold that heterojunction structures with mixed semiconductors, such as $\mathrm{TiO}_{2} / \mathrm{ZnO} / \mathrm{Bi}_{2} \mathrm{O}_{3}, 3 \mathrm{D} \mathrm{BiOCl}_{\mathrm{x}} \mathrm{Br}_{1-\mathrm{x}} /$ graphene oxide, could effectively improve the separation efficiency of photogenerated electron/hole and increase the subsequent photocatalytic activity. Meanwhile, some researcher suggested that bismuth might coexist in the form of $\mathrm{Bi}^{3+}$ and $\mathrm{Bi}_{2} \mathrm{O}_{3}$ over $\mathrm{Bi}$-doped $\mathrm{TiO}_{2}$ photocatalysts. $\mathrm{Li}$ et al. ${ }^{[39]}$ reported an ordinary approach, doping $\mathrm{Bi}_{2} \mathrm{O}_{3}$ powder into $\mathrm{TiO}_{2}$ sol, to synthesis $\mathrm{Bi}$ doped $\mathrm{TiO}_{2}$ photocatalyst. When the loading of $\mathrm{Bi}_{2} \mathrm{O}_{3}$ exceed $5 \mathrm{~mol} \%, \mathrm{Bi}_{2} \mathrm{Ti}_{4} \mathrm{O}_{11}$ phase 
started to appear and showed a good crystallization. The calcination temperature had a key effect on the chemical state of $\mathrm{Bi}$, a direct effect on the photocatalytic activity. Attributed to the synergetic effect of $\mathrm{Bi}_{x} \mathrm{TiO}_{\mathrm{y}}$ and $\mathrm{TiO}_{2}$, the photocatalytic activity over Bi-doped $\mathrm{TiO}_{2}$ could be improved. Gao et al. ${ }^{[30]}$ found that $\mathrm{Bi}_{4} \mathrm{Ti}_{3} \mathrm{O}_{12}$ and $\mathrm{Fe}$-doped $\mathrm{Bi}_{4} \mathrm{Ti}_{3} \mathrm{O}_{12}$ nanosheets, described with a formula of $\left(\mathrm{Bi}_{2} \mathrm{O}_{2}\right)^{2+}\left(\mathrm{Bi}_{2} \mathrm{Ti}_{3} \mathrm{O}_{10}\right)^{2-}$, which was constructed with a $\mathrm{TiO}_{6}$ octahedral and a $\left(\mathrm{Bi}_{2} \mathrm{O}_{2}\right)^{2+}$ monolayer, displayed a high photocatalytic oxidation of bisphenol $\mathrm{A}$ and phenol, although not as good as $\mathrm{Au}-2 \% \mathrm{Fe} /$ $\mathrm{Bi}_{4} \mathrm{Ti}_{3} \mathrm{O}_{12}$ composite photocatalysts. According to the XPS analysis, XPS signals of $\mathrm{Bi}_{2} \mathrm{O}_{3}$ powders could also be found. Prabhakaran et al. ${ }^{[40]}$ reported that $\mathrm{Bi}$-doped and $\mathrm{Bi}-$ $\mathrm{N}$ co-doped $\mathrm{TiO}_{2}$ nanocomposites could exhibit preferable photocatalytic activities for fabric dye under visible light illumination. However, the results of XRD were different from the results of XPS. XRD spectra showed crystalline $\mathrm{Bi}_{2} \mathrm{O}_{3}$, while the positive shift of XPS peaks corresponding to $\mathrm{Bi}_{4} \mathrm{f}_{7 / 2}$ and $\mathrm{Bi} 4 \mathrm{f}_{5 / 2}$ might also be ascribed to $\mathrm{Bi}-\mathrm{O}-\mathrm{Ti}$ bonds formation on the photocatalyst surface.

To summarize, it is still difficult to clarify the state of $\mathrm{Bi}$, as composite oxides or mixed oxides, for obtaining a high activity over $\mathrm{Bi}$-doped $\mathrm{TiO}_{2}$ photocatalysts. $\mathrm{I}$ t is still necessary to investigate the state of $\mathrm{Bi}$ in-depth and find the rules between bismuth and $\mathrm{TiO}_{2}$ in $\mathrm{Bi}$-doped $\mathrm{TiO}_{2}$ with composite oxides or mixed oxides. The most attractive aspect of these photocatalysts is the synergistic combination of bismuth oxide and titanium oxide, as doped $\mathrm{Bi}$ ions substitute titanium atoms in the form of compound oxidation or doped $\mathrm{Bi}_{2} \mathrm{O}_{3}$ with $\mathrm{TiO}_{2}$ in the form of heterojunction structure. Different from previous studies that some simple approaches have been developed to synthesize Bi-doped $\mathrm{TiO}_{2}$ photocatalysts with the formation of $\mathrm{Bi}_{x} \mathrm{TiO}_{y}$ or $\mathrm{Bi}_{2} \mathrm{O}_{3}-\mathrm{TiO}_{2}$, bismuth and titanium oxide with composite oxides or mixed oxides were produced for photocatalytic oxidation of low concentration of $\mathrm{HCHO}$ under visible light irradiation in this study. The possible mechanism of photocatalytic activities of $\mathrm{Bi}_{x} \mathrm{TiO}_{\mathrm{y}}$ and $\mathrm{Bi}_{2} \mathrm{O}_{3}-$ $\mathrm{TiO}_{2}$ was discussed. This research provides a better understanding of the different composite oxides or mixed oxides in the process of photocatalytic oxidation of $\mathrm{HCHO}$.

\section{Materials and Methods}

\subsection{Syntheses of photocatalysts}


All reagents, such as ethanol, glycerol and acetic acid, were analytical grade and were used without further purification in the experiments. For comparison, three different types of $\mathrm{Bi}$-doped $\mathrm{TiO}_{2}$ photocatalysts were prepared.

The first one was for $\mathrm{Bi}^{3+} / \mathrm{TiO}_{2}$ as composite oxides. $14.3 \mathrm{~mL}$ tetrabutyl titanate was added into $8.5 \mathrm{~mL}$ ethanol and $8.5 \mathrm{~mL}$ glycerol in a conical flask, denoted as solution A with a constant magnetic stirring. $3.2 \mathrm{~g}$ bismuth nitrate $\left(\mathrm{Bi}\left(\mathrm{NO}_{3}\right)_{3} \cdot 5 \mathrm{H}_{2} \mathrm{O}\right)$ and $0.4 \mathrm{~g}$ ammonium carbonate $\left(\left(\mathrm{NH}_{4}\right)_{2} \mathrm{CO}_{3}\right)$ were dissolved into $8.5 \mathrm{~mL}$ ethanol, $8.5 \mathrm{~mL}$ glycerol and $6.6 \mathrm{~mL}$ acetic acid, denoted as solution $\mathrm{B}$ with the magnetic mixture. Later, the solution B dropped into solution A with constant agitation. The resulting solution was stirred for $30 \mathrm{~min}$ and transfer into a stainless steel reactor for 2 days aging at 110 ${ }^{\circ} \mathrm{C}$. Finally, the precipitate was centrifuged and scrubbed with using distilled water and ethanol for three times, and then dried at $80{ }^{\circ} \mathrm{C}$ for $2.5 \mathrm{~h}$ and calcined at $450{ }^{\circ} \mathrm{C}$ for $8.5 \mathrm{~h}$ [41].

The second were for $\mathrm{Bi}_{2} \mathrm{O}_{3}-\mathrm{C} / \mathrm{TiO}_{2}$ and $\mathrm{Bi}_{2} \mathrm{O}_{3}-\mathrm{N} / \mathrm{TiO}_{2}$ as composite/mixed oxides. 3.2 g bismuth nitrate $\left(\mathrm{Bi}\left(\mathrm{NO}_{3}\right)_{3} \cdot 5 \mathrm{H}_{2} \mathrm{O}\right)$ was added into $100 \mathrm{~mL}$ distilled water with magnetic stirred until complete dissolution. $30 \mathrm{~mL}$ of $4 \mathrm{M} \mathrm{NaOH}$ aqueous solution was dropped until the $\mathrm{pH}$ at 12 . With a continuous stirring for $12 \mathrm{~h}$, the suspension was centrifuged and washed with distilled water twice, and then dried at $60{ }^{\circ} \mathrm{C}$ and calcined at $450{ }^{\circ} \mathrm{C}$ for $4 \mathrm{~h}$, denoted as $\mathrm{Bi}_{2} \mathrm{O}_{3}-\mathrm{C}$ powders, or not calcined at $450{ }^{\circ} \mathrm{C}$ for $4 \mathrm{~h}$, denoted as $\mathrm{Bi}_{2} \mathrm{O}_{3}-\mathrm{N}$ powders, to obtain two different powders $\left(\mathrm{Bi}_{2} \mathrm{O}_{3}-\mathrm{C}\right.$ and $\left.\mathrm{Bi}_{2} \mathrm{O}_{3}-\mathrm{N}\right)$. After that, another solution was prepared with the same way as $\mathrm{Bi}^{3+} / \mathrm{TiO}_{2}$ without bismuth nitrate, and then these $\mathrm{Bi}_{2} \mathrm{O}_{3}-\mathrm{C}$ or $\mathrm{Bi}_{2} \mathrm{O}_{3}-\mathrm{N}$ powders were added into the mixed solution together under constant agitation. After that, the resulting solution was stirred for 30 min and transfer into a stainless steel reactor for 2 days aging at $110{ }^{\circ} \mathrm{C}$. Finally, the precipitate was centrifuged and scrubbed with using distilled water and ethanol for three times, and then dried at $80{ }^{\circ} \mathrm{C}$ for $2.5 \mathrm{~h}$ and calcined at $450{ }^{\circ} \mathrm{C}$ for $8.5 \mathrm{~h}$. These catalysts were identified as $\mathrm{Bi}_{2} \mathrm{O}_{3}-\mathrm{C} / \mathrm{TiO}_{2}$ and $\mathrm{Bi}_{2} \mathrm{O}_{3}-\mathrm{N} / \mathrm{TiO}_{2}$.

The third one was for $\mathrm{Bi}_{2} \mathrm{O}_{3}-\mathrm{TiO}_{2}$ as mixed oxides. Two types of powders, such as $\mathrm{Bi}_{2} \mathrm{O}_{3}-\mathrm{N}$ and $\mathrm{TiO}_{2}$, were synthesized in the same way as above. And then, these two kinds of $\mathrm{Bi}_{2} \mathrm{O}_{3}-\mathrm{N}$ and $\mathrm{TiO}_{2}$ powders were mixed with mechanical blending, confirmed 
as $\mathrm{Bi}_{2} \mathrm{O}_{3}-\mathrm{TiO}_{2}$.

\subsection{Characterization}

The crystal structures of three different styles of photocatalysts were all detected by using a D/max-RB X-ray diffractometer (XRD, D8 Advance, Bruker, Germany) equipped with $\mathrm{Cu} \mathrm{K \alpha}$ radiation $(\lambda=0.15406 \mathrm{~nm})$ in a $2 \theta$ range of $10-80^{\circ}$ and the scanning speed was $4 \%$ min. Raman spectra were measurement on Renishaw inVia Raman systems at ambient temperature and fitted with the $532 \mathrm{~nm}$ line of an Ar ion laser as an excitation source. The microscopic morphological structure and particle size of these prepared samples were observed by using a scanning electron microscope (SEM, Hitachi S-4800, Hitachi, Japan) and a transmission electron microscope (TEM, JEM-2100, JEOL, Japan). The Brunauer-Emmett-Teller (BET, ASAP-2020, Micromeritics Instrument Corporation, USA) surface areas of the spent catalysts and pre-treated were determined by using nitrogen adsorption at $77.3 \mathrm{~K}$. The UV-vis spectra (UV-vis, Lambda 950, Perkin-Elmer, USA) of samples were recorded with an integrating sphere attachment. The scanning range was between $250 \mathrm{~nm}$ and $800 \mathrm{~nm}$, and $\mathrm{BaSO}_{4}$ was used as a reference. The excited states of these catalysts composite were detected with photoluminescence (PL, MicOS, HORIBA Scientific, USA). In-situ diffuse reflectance infrared transform spectrometry (DRIFTS, Nicolet 6700FTIR, Thermo, USA) was carried out on a spectrometer fitted with a MCT detector and a hightemperature reaction chamber, which could supply all the necessary gas inlets or outlets and allow for measuring and controlling the temperature. The spectra could be acquired with an accumulation of 64 scans and a resolution of $4 \mathrm{~cm}^{-1}$. IR spectra (Nicolet 410 FTIR, Thermo, USA) on KBr pellets of the samples were recorded on a spectrometer at a resolution of $4 \mathrm{~cm}^{-1}$. The concentration of the samples in $\mathrm{KBr}$ was maintained at approximately $0.3 \%$. The X-ray photoelectron spectroscopy (XPS, AXIS ULTRADLD, Shimadzu-Krotos, Japan) spectra were obtained by using an AlK $\alpha$ X-ray source (1486.6 $\mathrm{eV}$ ) operated at $15 \mathrm{kV}$ and $300 \mathrm{~W}$ with an ESCALAB250 Thermo VG to understand the chemical binding energies of the $\mathrm{Bi}, \mathrm{Ti}$ and $\mathrm{O}$. Electron paramagnetic resonance (EPR, JES-FA200, JEOL, Japan) spectra was collected from a spectrometer with employing an $\mathrm{X}$-band microwave frequency $(9.43 \mathrm{GHz})$ and power $(1.5 \mathrm{~mW})$ at room 
temperature.

\subsection{Activity evaluation of $\mathrm{HCHO}$ removal}

The photocatalytic degradation of $\mathrm{HCHO}$ over $\mathrm{Bi}$-doped $\mathrm{TiO}_{2}$ catalysts was carried out in a self-designed glass reactor $(600 \times 600 \times 600 \mathrm{~mm})$. $1 \mathrm{~mL} \mathrm{HCHO}(38 \mathrm{wt} \%)$ was dropped into a petri dish and removed into this glass reactor for five minutes. When the concentration was $1.05 \pm 0.05 \mathrm{mg} / \mathrm{m}^{3}$, the petri dish was moved out and another petri dish with $0.4 \mathrm{~g}$ photocatalyst powder was transferred into the glass reactor quickly. After that, the glass reactor was immediately sealed by using a glass cover with vaseline. Through a small hole in the front of the glass reactor, the concentration of formaldehyde was detected by using a formaldehyde meter (PPM-400st, PPM Technology, UK), which designed to measure $\mathrm{HCHO}$ concentrations from 0 to $24.56 \mathrm{mg} / \mathrm{m}^{3}$ in snatch samples of air. A 36W energy-saving lamp (LED) providing the visible light was fixed $10 \mathrm{~cm}$ above the catalyst. When the concentration became stable and the adsorptiondesorption equilibrium remained, the energy-saving lamp was turned on and $\mathrm{HCHO}$ concentration was measured using the PPM-400st meter for three times at every $12 \mathrm{~h}$. To investigate the photocatalytic activity of different catalysts, a set of gaseous experiments were carried out in the indoor environment.

\section{Results and discussion}

\subsection{The activity of $\mathrm{Bi}$-doped $\mathrm{TiO}_{2}$ for $\mathrm{HCHO}$ oxidation}

Fig. 1 shows the conversion of $\mathrm{HCHO}$ and stability under visible light irradiation over different types of $\mathrm{Bi}$-doped $\mathrm{TiO}_{2}$ photocatalysts as a function of time. The conditions in standard tests were composed of $\mathrm{HCHO}$ concentration $\left(1.05 \pm 0.05 \mathrm{mg} / \mathrm{m}^{3}\right)$, reaction temperature $\left(20-30^{\circ} \mathrm{C}\right)$, LED type $(36 \mathrm{~W})$ and catalyst powder $(0.40 \mathrm{~g})$. In terms of the blank and adsorption tests over $\mathrm{TiO}_{2}, \mathrm{Bi}_{2} \mathrm{O}_{3}$ and $\mathrm{Bi}^{3+} / \mathrm{TiO}_{2}$ catalysts under dark, the concentration of $\mathrm{HCHO}$ decreased from 1.052 to $0.923 \mathrm{mg} / \mathrm{m}^{3}$ at $48 \mathrm{~h}$ in the blank (Fig. $1(\mathrm{~A})$ ), indicating that the glass reactor owned good airtightness without HCHO leakage. Although the $\mathrm{Bi}^{3+} / \mathrm{TiO}_{2}$ photocatalysts exhibited better adsorption than $\mathrm{TiO}_{2}$ and $\mathrm{Bi}_{2} \mathrm{O}_{3}$, the adsorption amount of $\mathrm{HCHO}$ was still very low, even negligible. In terms of the photocatalytic activity and stability over these Bi-doped $\mathrm{TiO}_{2}$ catalysts, the photocatalytic activity and stability of $\mathrm{Bi}^{3+} / \mathrm{TiO}_{2}$ were significantly higher than other 
232 three kinds of Bi-doped $\mathrm{TiO}_{2}$ catalysts due to the composition and structure (Fig. 1(B) 233 and (C)). The HCHO concentration decreased from 1.094 to $0.058 \mathrm{mg} / \mathrm{m}^{3}$ at $36 \mathrm{~h}$, even 234 below the limits value of standard $\left(0.08 \mathrm{mg} / \mathrm{m}^{3}\right)$. Moreover, the catalyst demonstrated 235 good stability with four consecutive tests. However, $\mathrm{Bi}_{2} \mathrm{O}_{3}-\mathrm{N} / \mathrm{TiO}_{2}, \mathrm{Bi}_{2} \mathrm{O}_{3}-\mathrm{C} / \mathrm{TiO}_{2}$, and $236 \mathrm{Bi}_{2} \mathrm{O}_{3}-\mathrm{TiO}_{2}$ catalysts showed the same activity for $\mathrm{HCHO}$ degradation and the 237 conversion was about $50 \%$ at $48 \mathrm{~h}$. Meanwhile, the stability of $\mathrm{Bi}_{2} \mathrm{O}_{3}-\mathrm{N} / \mathrm{TiO}_{2}$ was as bad 238 as its oxidation activity, without improving. Owing to the rapid recombination of 239 photogenerated electrons and holes, although $\mathrm{Bi}_{2} \mathrm{O}_{3}$ owned lower band gap energy (2.9 $240 \mathrm{eV})$ than $\mathrm{TiO}_{2}(3.2 \mathrm{eV})$, it exhibited the lowest activity for $\mathrm{HCHO}$ oxidation.

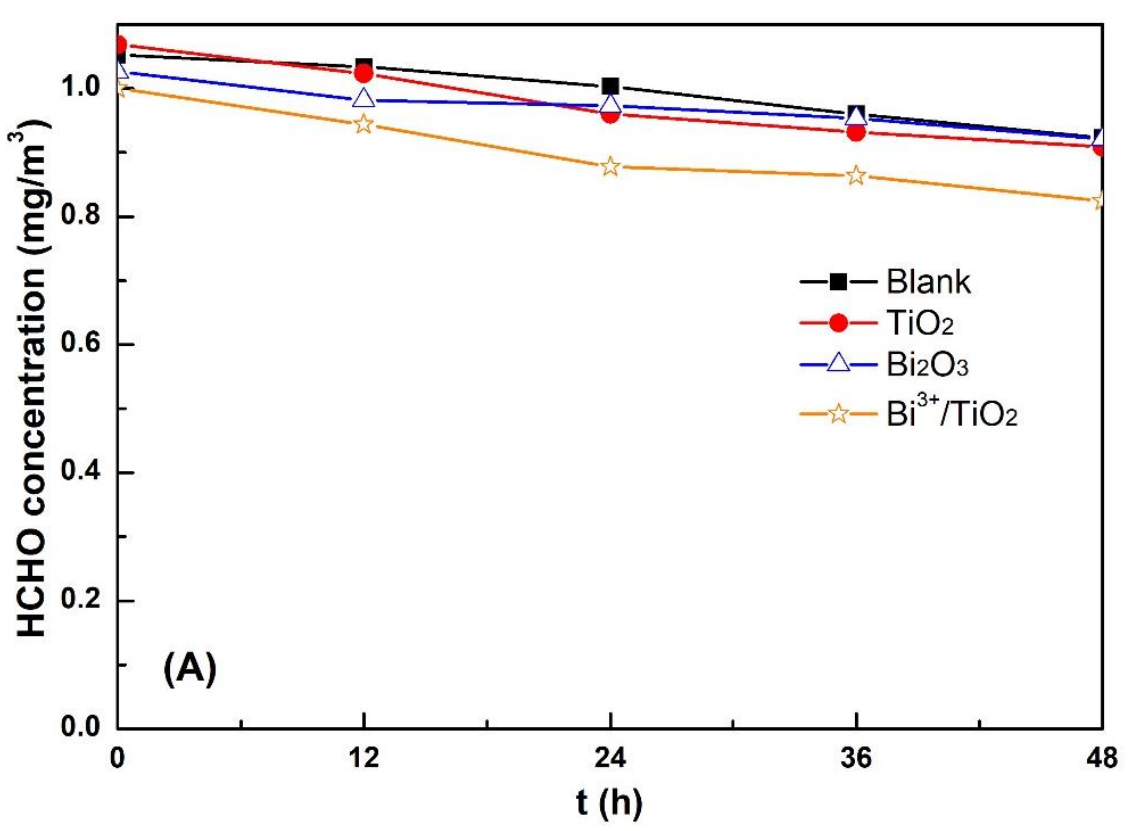



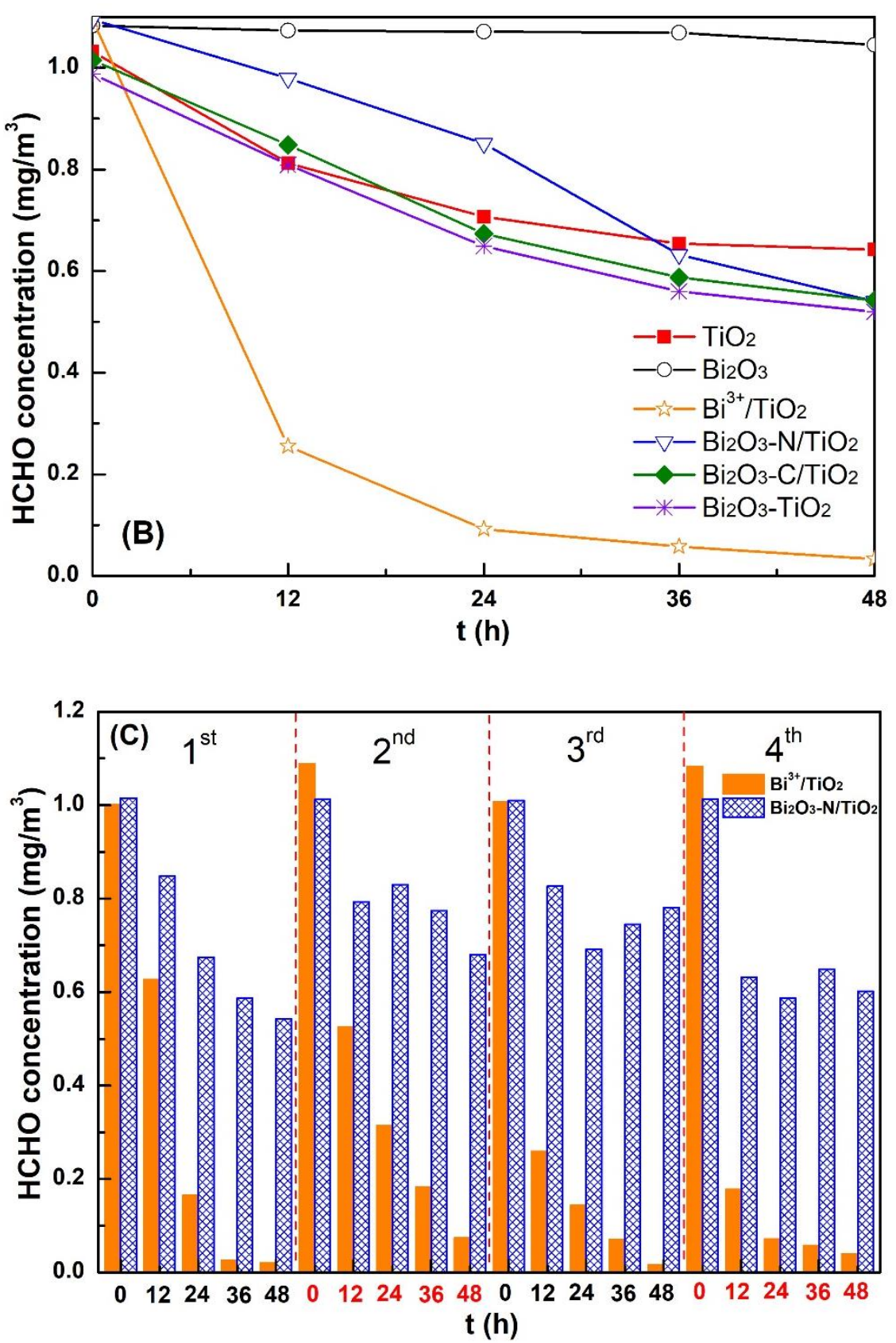

Fig. 1. Photocatalytic degradation of $\mathrm{HCHO}$ and stability over $\mathrm{Bi}$-doped $\mathrm{TiO}_{2}$ catalysts (A: blank and adsorption experiments under dark; $\mathrm{B}$ : photocatalytic oxidation of $\mathrm{HCHO}$ over $\mathrm{Bi}$-doped $\mathrm{TiO}_{2}$ catalysts; $\mathrm{C}$ : stability experiments over $\mathrm{Bi}^{3+} / \mathrm{TiO}_{2}$ and $\mathrm{Bi}_{2} \mathrm{O}_{3}-\mathrm{N} / \mathrm{TiO}_{2}$ with four times )

\subsection{XRD analysis}

Fig. 2 shows the XRD patterns of Bi-doped $\mathrm{TiO}_{2}$ catalysts with different preparation methods calcinated at $450{ }^{\circ} \mathrm{C}$ for $8.5 \mathrm{~h}$. For comparison, the XRD patterns of the asprepared pure $\mathrm{Bi}_{2} \mathrm{O}_{3}$ and $\mathrm{TiO}_{2}$ were also provided. The XRD patterns of $\mathrm{TiO}_{2}$ and $\mathrm{Bi}_{2} \mathrm{O}_{3}$ were corresponded to the anatase phase of $\mathrm{TiO}_{2}(\mathrm{PDF} \#$ 21-1272) and the monoclinic phase of $\alpha-\mathrm{Bi}_{2} \mathrm{O}_{3}$ (PDF \# 41-1449), respectively. Both of them showed good crystal 
structures with the sharp diffraction peaks accompanied by calcinating at $450{ }^{\circ} \mathrm{C}$ for 8.5 $\mathrm{h}$ and the crystal peaks were calculated by using the Scherrer equation attributed to (1

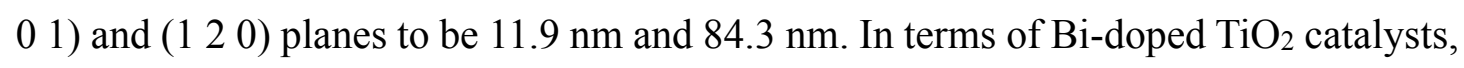
except for $\mathrm{Bi}_{2} \mathrm{O}_{3}-\mathrm{TiO}_{2}$ mixed oxides, the XRD patterns of $\mathrm{Bi}^{3+} / \mathrm{TiO}_{2}$ were assigned to anatase $\mathrm{TiO}_{2}$ and a new characteristic peak at $30.2^{\circ}$ and $33.1^{\circ}$ ascribed to the composite oxide of $\mathrm{Bi}_{4} \mathrm{Ti}_{3} \mathrm{O}_{12}$ (PDF \# 35-0795). Regarding $\mathrm{Bi}_{2} \mathrm{O}_{3}-\mathrm{N} / \mathrm{TiO}_{2}$ and $\mathrm{Bi}_{2} \mathrm{O}_{3}-\mathrm{C} / \mathrm{TiO}_{2}$ catalysts, the XRD patterns displayed almost the same diffraction peaks indexed to the monoclinic phase of $\alpha-\mathrm{Bi}_{2} \mathrm{O}_{3}$ and the composite oxide of $\mathrm{Bi}_{4} \mathrm{Ti}_{3} \mathrm{O}_{12}$, implying that $\mathrm{Bi}_{2} \mathrm{O}_{3}$ with calcining or not had no effect on the crystal structure. This is due to that these two kinds of $\mathrm{Bi}$-doped $\mathrm{TiO}_{2}$ catalysts composed of $\mathrm{Bi}_{2} \mathrm{O}_{3}$ and $\mathrm{Bi}_{4} \mathrm{Ti}_{3} \mathrm{O}_{12}$ led to a lower activity than $\mathrm{Bi}^{3+} / \mathrm{TiO}_{2}$. In terms of $\mathrm{Bi}_{2} \mathrm{O}_{3}-\mathrm{TiO}_{2}$ mixed oxide catalyst, the diffraction peaks in the patterns were ascribed to the $\mathrm{TiO}_{2}$ and $\alpha-\mathrm{Bi}_{2} \mathrm{O}_{3}$, respectively. Therefore, the above results indicated that the heterojunction structure with $\mathrm{TiO}_{2}$ and $\mathrm{Bi}_{4} \mathrm{Ti}_{3} \mathrm{O}_{12}$ was the critical factor to obtain a high activity for $\mathrm{HCHO}$ oxidation, rather than the incorporation of $\mathrm{Bi}_{2} \mathrm{O}_{3}$ and $\mathrm{Bi}_{4} \mathrm{Ti}_{3} \mathrm{O}_{12}$, even with $\mathrm{Bi}_{2} \mathrm{O}_{3}$ and $\mathrm{TiO}_{2}$.

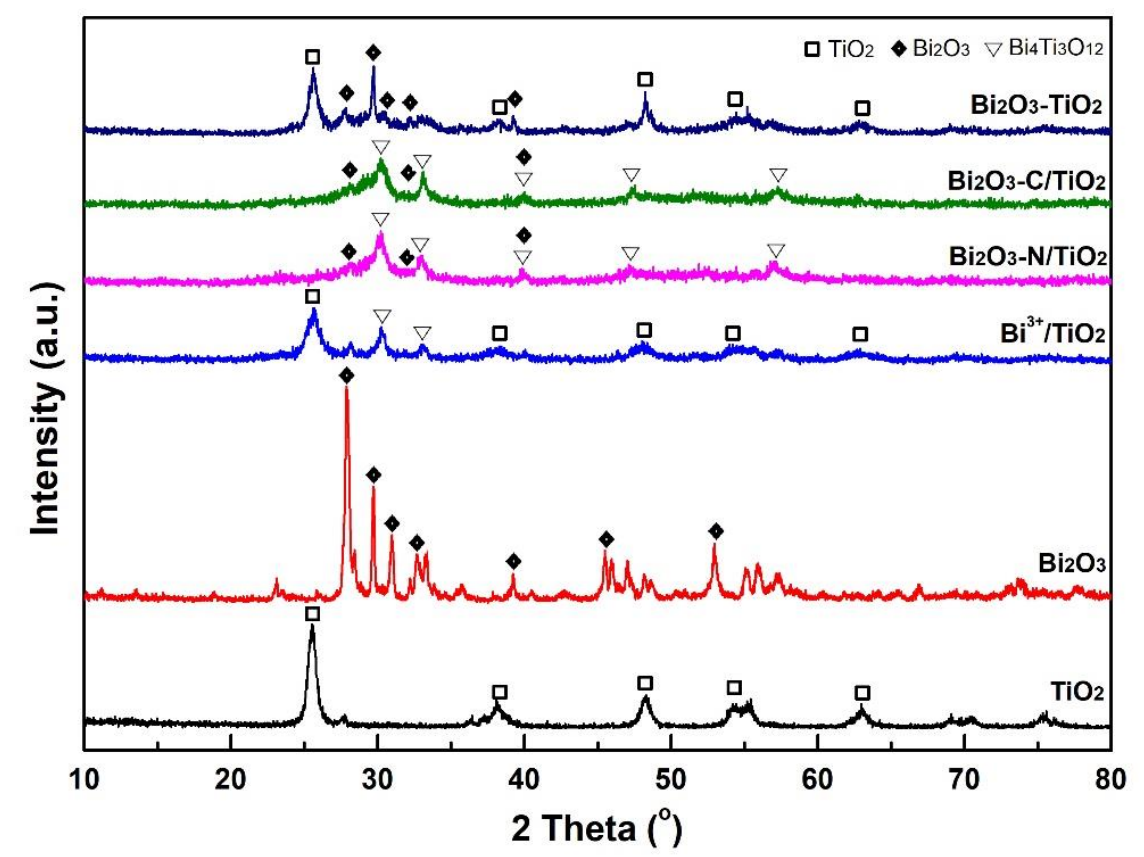

Fig. 2. XRD patterns of $\mathrm{TiO}_{2}, \mathrm{Bi}_{2} \mathrm{O}_{3}$, and $\mathrm{Bi}$-doped $\mathrm{TiO}_{2}$ catalysts 
Table 1. Textural properties of $\mathrm{TiO}_{2}, \mathrm{Bi}_{2} \mathrm{O}_{3}$, and $\mathrm{Bi}$-doped $\mathrm{TiO}_{2}$ catalysts

\begin{tabular}{cccc}
\hline Samples & $\boldsymbol{S}_{\mathbf{B E T}}\left(\mathbf{m}^{2} / \mathbf{g}\right)$ & $\boldsymbol{V}_{\mathbf{p}}\left(\mathbf{c m}^{3} / \mathbf{g}\right)$ & $\boldsymbol{d}_{\mathbf{p}}(\mathbf{n m})$ \\
\hline $\mathbf{T i O}_{2}$ & 59.53 & 0.11 & 5.76 \\
$\mathbf{B i}_{2} \mathbf{O}_{3}$ & 37.96 & 0.03 & 5.43 \\
$\mathbf{B i}^{3+} / \mathbf{T i O}_{2}$ & 52.39 & 0.12 & 7.82 \\
$\mathbf{B i}_{2} \mathbf{O}_{3}-\mathbf{N} / \mathbf{T i O}_{2}$ & 27.3 & 0.07 & 6.73 \\
$\mathbf{B i}_{2} \mathbf{O}_{3}-\mathbf{C} / \mathbf{T i O}_{2}$ & 42.78 & 0.10 & 7.23 \\
$\mathbf{B i}_{2} \mathbf{O}_{3}-\mathbf{T i O}_{2}$ & 50.51 & 0.11 & 6.67 \\
\hline
\end{tabular}

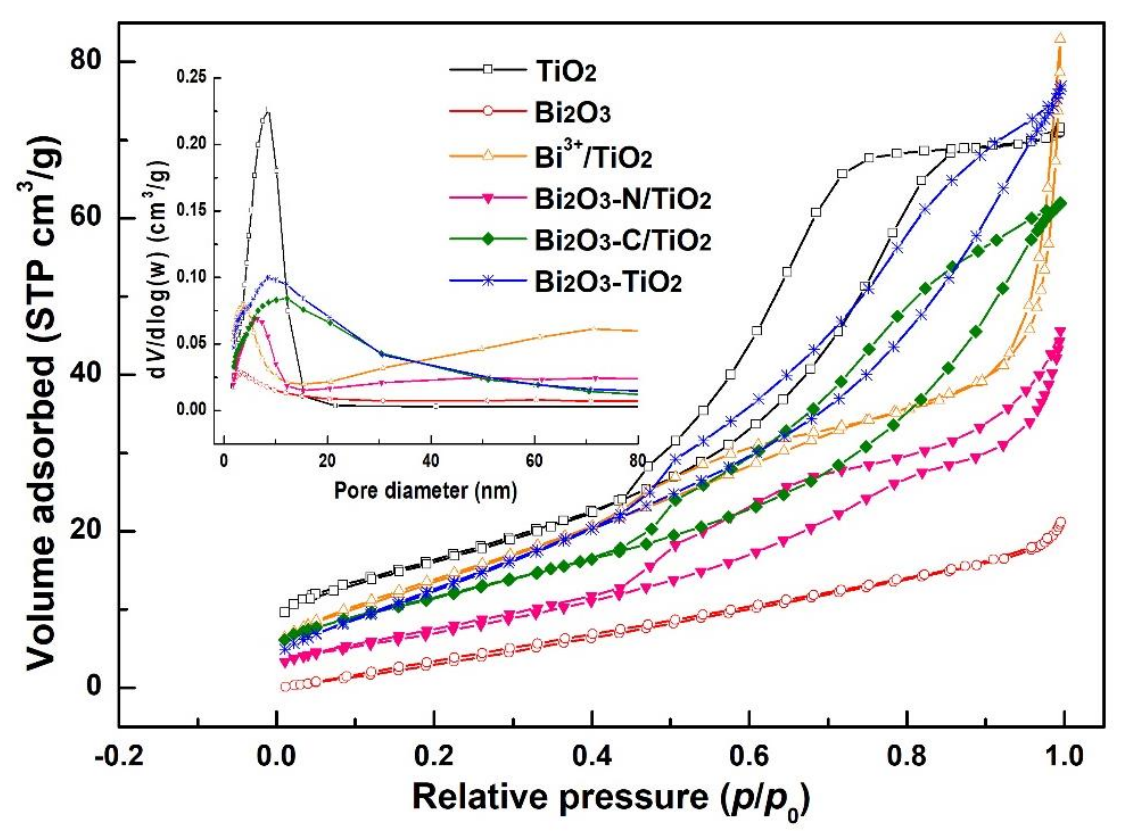

Fig. 3. Nitrogen adsorption-desorption isotherms and pore-size distribution curves of $\mathrm{TiO}_{2}, \mathrm{Bi}_{2} \mathrm{O}_{3}$, and $\mathrm{Bi}$-doped $\mathrm{TiO}_{2}$ catalysts

In general, the large surface areas of catalysts can provide more active sites to adsorbent reactant molecules and then oxidize, which can effectively improve the activity of $\mathrm{HCHO}$ oxidation. Fig. 3 shows $\mathrm{N}_{2}$ adsorption-desorption isotherms and the appropriate pore size distribution curves of different types of $\mathrm{Bi}$-doped $\mathrm{TiO}_{2}$ catalysts. The isotherms of $\mathrm{TiO}_{2}$ displayed a type IV isotherm with a $\mathrm{H} 2$ hysteresis loops, which may include typical "ink bottle" holes, tubular holes with uneven pore size distribution, or densely packed spherical particle interstitial holes, etc. Bi-doped $\mathrm{TiO}_{2}$ catalysts, except for $\mathrm{Bi}^{3+} / \mathrm{TiO}_{2}$, showed adsorption-desorption isotherms of type IV with an overlap of $\mathrm{H} 2$ and $\mathrm{H} 3$ hysteresis loops, resulting from bottle-ink and slit-like pores, signifying that the pore sizes of these samples lied in the range of 2-50 $\mathrm{nm}$. The result could also be 
confirmed by the pore size distribution and the result of BET (Table 1) and SEM (Fig. 5), which demonstrated that the pore sizes of these samples were from 5 to $8 \mathrm{~nm}$. However, $\mathrm{Bi}^{3+} / \mathrm{TiO}_{2}$ displayed two distinct hysteresis loops, implying that one of the hysteresis loops was the channel in these particles and the other should be the accumulation hole of the particles. The result implied that $\mathrm{Bi}^{3+} / \mathrm{TiO}_{2}$ had larger channels, which was also confirmed by the pore size distribution and the improved HCHO adsorption. $\mathrm{Bi}^{3+} / \mathrm{TiO}_{2}\left(\mathrm{~S}_{\mathrm{BET}}=52.39 \mathrm{~m}^{2} / \mathrm{g}\right)$ exhibited the largest surface areas and pore sizes among these different types of Bi-doped $\mathrm{TiO}_{2}$ catalysts. In addition, the surface areas of $\mathrm{TiO}_{2}$ and $\mathrm{Bi}_{2} \mathrm{O}_{3}$ were calculated to be $59.53 \mathrm{~m}^{2} / \mathrm{g}$ and $37.96 \mathrm{~m}^{2} / \mathrm{g}$, respectively. $\mathrm{Bi}_{2} \mathrm{O}_{3}$ and $\mathrm{Bi}_{2} \mathrm{O}_{3}-\mathrm{N} / \mathrm{TiO}_{2}$ exhibited extremely low pore volume, which were aligned with the adsorption-desorption isotherms, and these could significantly decrease the adsorption of $\mathrm{HCHO}$ and be detrimental for the improvement of oxidation activity. Therefore, the above results demonstrated that the specific surface areas maybe not the most important factor for photocatalytic oxidation of $\mathrm{HCHO}$, but it could display a minor role in the activity enhancement.

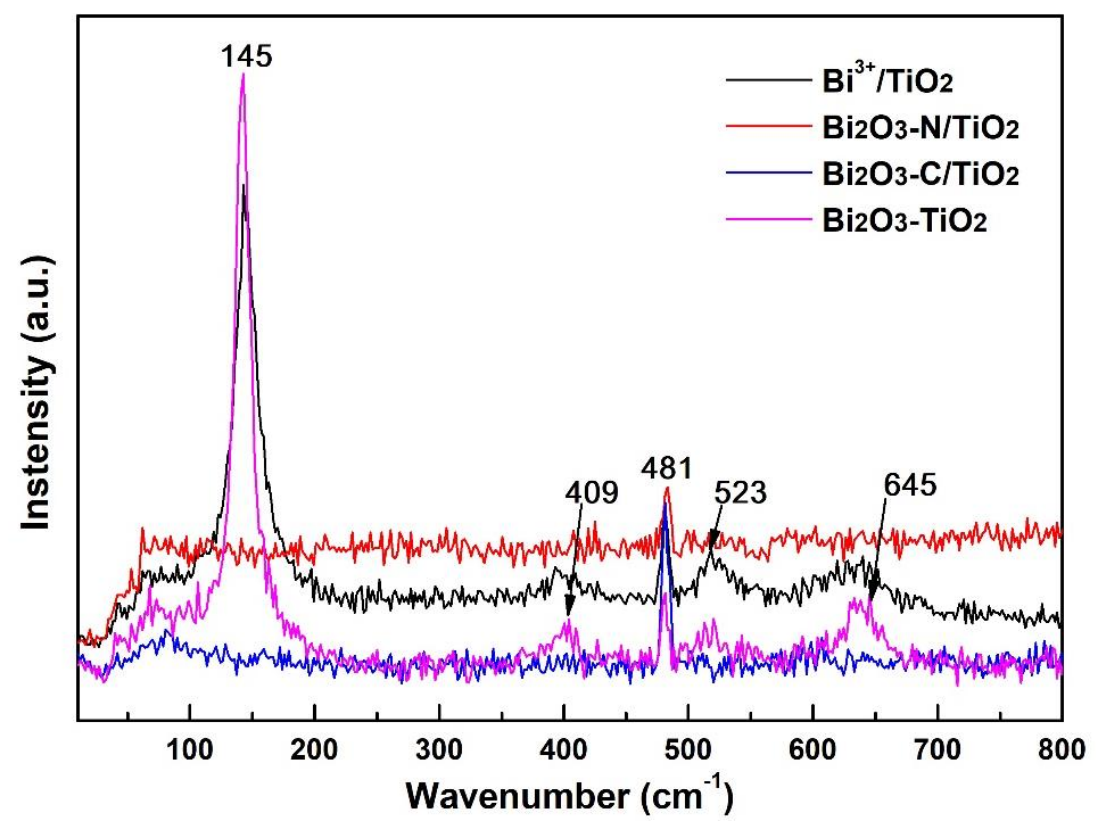

Fig. 4. Raman spectra of Bi-doped $\mathrm{TiO}_{2}$ catalysts

Fig. 4 shows the Raman spectra of Bi-doped catalysts with different synthetic methods.

The peaks at 145, 409, 523 and $645 \mathrm{~cm}^{-1}$ could be identified to the characteristic bands 
of anatase $\mathrm{TiO}_{2}{ }^{[39]}$, indicating that the $\mathrm{TiO}_{2}$ was one of the main phase structures in the sample of $\mathrm{Bi}^{3+} / \mathrm{TiO}_{2}$ and $\mathrm{Bi}_{2} \mathrm{O}_{3}-\mathrm{TiO}_{2}$, which was consistent with the XRD results. While for $\mathrm{Bi}_{2} \mathrm{O}_{3}-\mathrm{N} / \mathrm{TiO}_{2}$ and $\mathrm{Bi}_{2} \mathrm{O}_{3}-\mathrm{C} / \mathrm{TiO}_{2}$, it was difficult to detect the presence of anatase $\mathrm{TiO}_{2}$ by Raman spectra. More importantly, the Raman peak at $481 \mathrm{~cm}^{-1}$ could be assigned to the characteristic band of $\mathrm{Bi}_{2} \mathrm{O}_{3}$. Among these samples, the $\mathrm{Bi}_{2} \mathrm{O}_{3}-\mathrm{C} / \mathrm{TiO}_{2}$ exhibited the strongest intensity due to $\mathrm{Bi}_{2} \mathrm{O}_{3}$ powder calcined at $450{ }^{\circ} \mathrm{C}$ for $4 \mathrm{~h}$. While for $\mathrm{Bi}_{2} \mathrm{O}_{3}-\mathrm{N} / \mathrm{TiO}_{2}, \mathrm{Bi}_{2} \mathrm{O}_{3}-\mathrm{C}_{2} / \mathrm{TiO}_{2}$ and $\mathrm{Bi}^{3+} / \mathrm{TiO}_{2}$, it was easy to find the presence of $\mathrm{Bi}_{4} \mathrm{Ti}_{3} \mathrm{O}_{12}$, not $\mathrm{Bi}_{2} \mathrm{O}_{3}$, by the XRD measurement, which was not corroborate well with Raman spectra. That was because the composite oxides of $\mathrm{Bi}_{4} \mathrm{Ti}_{3} \mathrm{O}_{12}$ contained the characteristic band of $\mathrm{Bi}_{2} \mathrm{O}_{3}$.

\subsection{Morphology measurement}

The morphology structure of $\mathrm{TiO}_{2}, \mathrm{Bi}_{2} \mathrm{O}_{3}$, and $\mathrm{Bi}$-doped $\mathrm{TiO}_{2}$ catalysts were investigated by using SEM and $\mathrm{TEM}$. $\mathrm{TiO}_{2}$ showed an aggregated of lumpy particles with a smooth surface, while $\mathrm{Bi}_{2} \mathrm{O}_{3}$ displayed some aggregated and smaller particles with a rough surface attributed to nano-sized spherical $\mathrm{Bi}_{2} \mathrm{O}_{3}$ (Fig. 5(B)). $\mathrm{Bi}_{2} \mathrm{O}_{3}-\mathrm{TiO}_{2}$ (Fig. 5(C)) mixed oxides with $\mathrm{TiO}_{2}$ and $\mathrm{Bi}_{2} \mathrm{O}_{3}$ exhibited the same image as the images of Fig. 5(A) and Fig. 5(B) without changing. Regarding Bi-doped $\mathrm{TiO}_{2}$ catalysts (Fig. 5(D-F)), SEM image of $\mathrm{Bi}^{3+} / \mathrm{TiO}_{2}$ composites that were composed of mutually aggregated spherical nanoparticles showed a uniform particulate state and it could improve the adsorption of visible light and $\mathrm{HCHO}$ to increase the activity. While, samples of $\mathrm{Bi}_{2} \mathrm{O}_{3}-\mathrm{N} / \mathrm{TiO}_{2}$ and $\mathrm{Bi}_{2} \mathrm{O}_{3}-\mathrm{C} / \mathrm{TiO}_{2}$ calcined at $450{ }^{\circ} \mathrm{C}$ for $8.5 \mathrm{~h}$ displayed irregular and smooth-surfaced lumps, indicated that there was a meltingrecrystallization-remelting process for these composites. As can be seen in Fig. 5(G), the observed lattice spacing of $0.234 \mathrm{~nm}$ was attributed to the $\left(\begin{array}{lll}0 & 14\end{array}\right)$ crystal planes of $\mathrm{Bi}_{4} \mathrm{Ti}_{3} \mathrm{O}_{4}$, and lattice spacing of $0.243 \mathrm{~nm}$ and $0.166 \mathrm{~nm}$ (not shown) corresponded to the (llll $\left.\begin{array}{lll}1 & 0\end{array}\right)$ and $\left(\begin{array}{lll}2 & 1 & 1\end{array}\right)$ crystal planes of anatase $\mathrm{TiO}_{2}$, respectively. However, the images of $\mathrm{Bi}_{2} \mathrm{O}_{3}-\mathrm{N} / \mathrm{TiO}_{2}$ and $\mathrm{Bi}_{2} \mathrm{O}_{3}-\mathrm{C} / \mathrm{TiO}_{2}$ catalysts exhibited that these particles aggregated together and produced a large number of lumps with a smooth surface due to roasted $\mathrm{Bi}_{2} \mathrm{O}_{3}$ without doping into $\mathrm{TiO}_{2}$. According to Fig. 5(H), the lattice spacing of 0.234 $\mathrm{nm}, 0.271 \mathrm{~nm}, 0.269 \mathrm{~nm}$ and $0.256 \mathrm{~nm}$ matched well with the (0 140$)$ crystal planes of 
$337 \mathrm{Bi}_{4} \mathrm{Ti}_{3} \mathrm{O}_{4}$ and the (-1 2 2), ( $\left.\begin{array}{lll}2 & 2 & 0\end{array}\right)$, and (-2 12 ) crystal planes of $\mathrm{Bi}_{2} \mathrm{O}_{3}$ (not shown). The

338 above results were all in accordance with the XRD exhibited in Fig. 2.

339
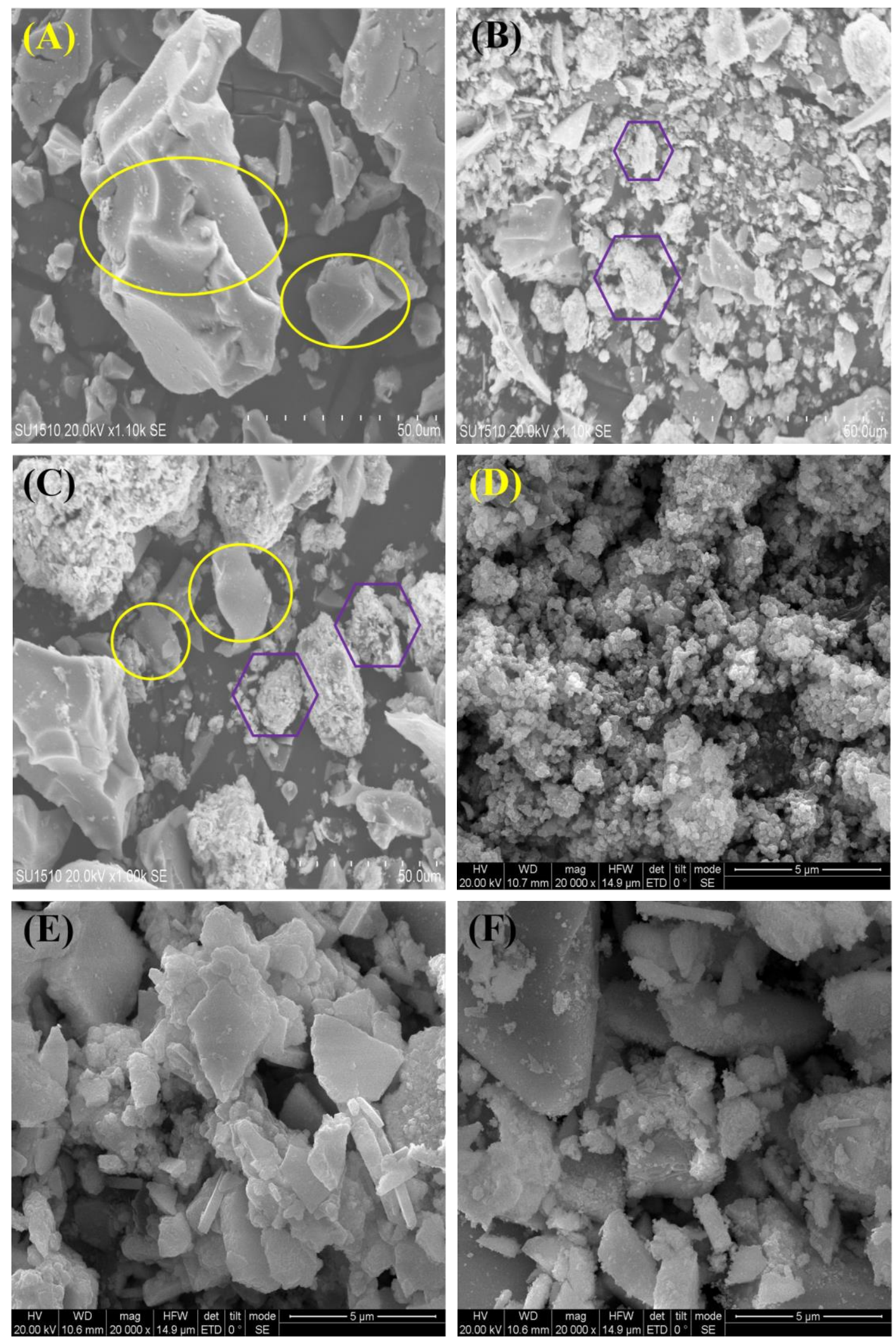

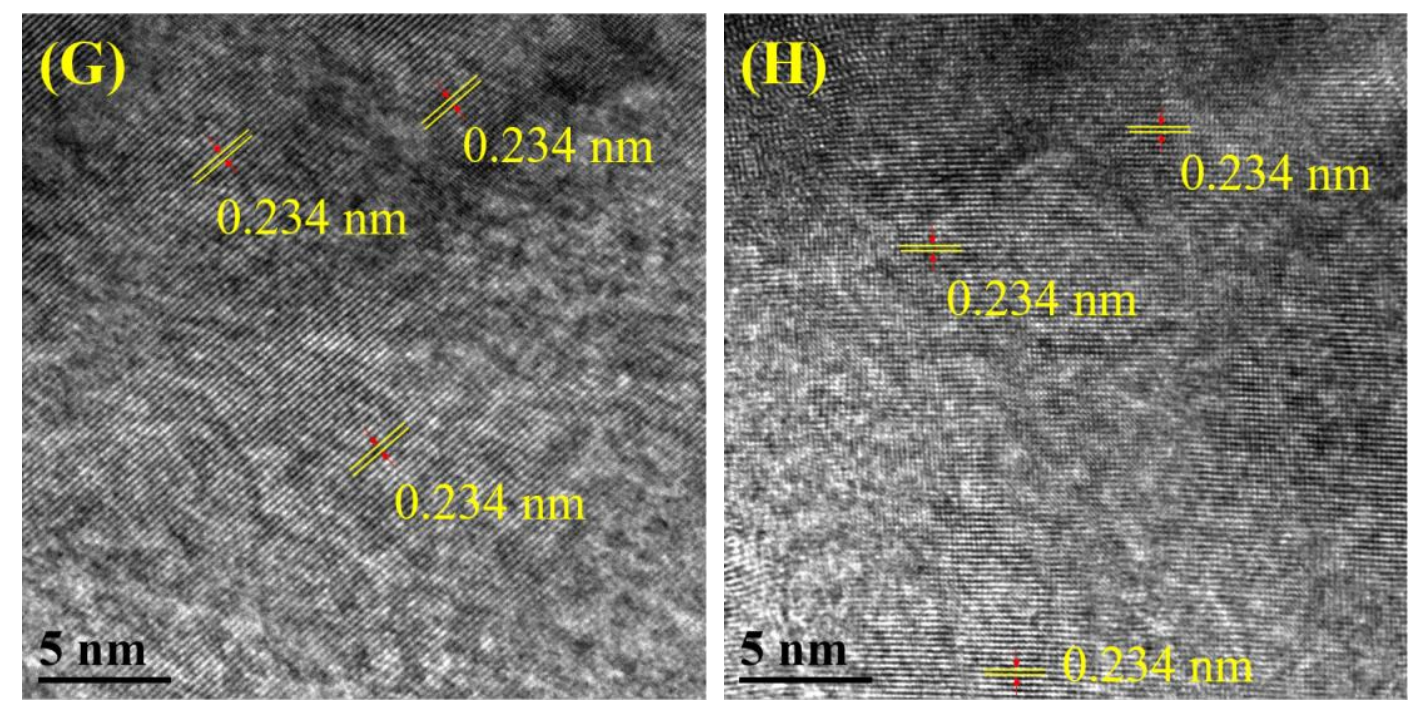

Fig. 5 SEM and TEM images of photocatalysts: (A) $\mathrm{TiO}_{2}$, (B) $\mathrm{Bi}_{2} \mathrm{O}_{3},(C) \mathrm{Bi}_{2} \mathrm{O}_{3}-\mathrm{TiO}_{2},(\mathrm{D}, \mathrm{G})$

$$
\mathrm{Bi}^{3+} / \mathrm{TiO}_{2},(\mathrm{E}, \mathrm{H}) \mathrm{Bi}_{2} \mathrm{O}_{3}-\mathrm{N} / \mathrm{TiO}_{2} \text {, and }(\mathrm{F}) \mathrm{Bi}_{2} \mathrm{O}_{3}-\mathrm{C} / \mathrm{TiO}_{2}
$$

\subsection{Optical absorption properties}

The corresponding UV-vis DRS and PL spectra of $\mathrm{TiO}_{2}, \mathrm{Bi}_{2} \mathrm{O}_{3}$ and $\mathrm{Bi}$-doped $\mathrm{TiO}_{2}$ catalysts are presented in Fig. 6. The absorption peak of pure $\mathrm{TiO}_{2}$ at $380-780 \mathrm{~nm}$ could be found as anatase $\mathrm{TiO}_{2}$ and the band gap energy $\left(E_{g}\right)$ was $3.1 \mathrm{eV}$, which displayed visible light absorption and low $E_{g}(3.2 \mathrm{eV})$ due to the incorporation of $\mathrm{N}$ or $\mathrm{C}$ with $\left(\mathrm{NH}_{4}\right)_{2} \mathrm{CO}_{3}$. The absorption intensities of $\mathrm{Bi}_{2} \mathrm{O}_{3}$ with the $E_{g}$ of approximately $2.9 \mathrm{eV}$ in the visible region from 380 to $450 \mathrm{~nm}$ were markedly higher than those in other visible regions. $\mathrm{Bi}_{2} \mathrm{O}_{3}$ displayed visible light absorption and low $E_{g}$, and it exhibited the worse activity than other samples due to the rapid recombination of photogenerated $\mathrm{e}^{-}$and $\mathrm{h}^{+}$. Therefore, $\mathrm{Bi}_{2} \mathrm{O}_{3}$ couldn't be used independently as an oxide catalyst for HCHO oxidation and it needed to be combined with other semiconductors, such as $\mathrm{TiO}_{2}$, to

356 form heterojunctions structure or others to improve the oxidation activity. In terms of 357 Bi-doped $\mathrm{TiO}_{2}$ samples, $\mathrm{Bi}^{3+} / \mathrm{TiO}_{2}$ with the $E_{g}$ of around $3.0 \mathrm{eV}$ exhibited the highest 358 absorption at UV and visible regions, so it showed the highest activity for HCHO 359 degradation at ambient temperature. $\mathrm{Bi}_{2} \mathrm{O}_{3}-\mathrm{N} / \mathrm{TiO}_{2}$ and $\mathrm{Bi}_{2} \mathrm{O}_{3}-\mathrm{C} / \mathrm{TiO}_{2}$ displayed almost 360 the same visible light absorption and $E_{g}(2.8 \mathrm{eV})$ owing to the rapid recombination of 361 photogenerated $\mathrm{e}^{-}$and $\mathrm{h}^{+}$with $\mathrm{Bi}_{2} \mathrm{O}_{3}$. Therefore, the samples of $\mathrm{Bi}_{2} \mathrm{O}_{3}-\mathrm{N} / \mathrm{TiO}_{2}$ and $362 \mathrm{Bi}_{2} \mathrm{O}_{3}-\mathrm{C} / \mathrm{TiO}_{2}$ displayed poor activities for $\mathrm{HCHO}$ oxidation. The above results were all 363 consistent with the activity of $\mathrm{Bi}$-doped $\mathrm{TiO}_{2}$ for $\mathrm{HCHO}$ oxidation. 
The PL spectra were designed to evaluate the excited state of photocatalysts and the recombination rate of photoinduced $\mathrm{e}^{-}$and $\mathrm{h}^{+}$. In this study, the excitation wavelength was $325 \mathrm{~nm}$ at room temperature and examined in the range of 350-900 nm with a single scan mode. Fig. 6(C) shows the PL spectra of $\mathrm{Bi}_{2} \mathrm{O}_{3}-\mathrm{N} / \mathrm{TiO}_{2}, \mathrm{Bi}_{2} \mathrm{O}_{3}-\mathrm{C} / \mathrm{TiO}_{2}$, $\mathrm{Bi}^{3+} / \mathrm{TiO}_{2}$ and $\mathrm{Bi}_{2} \mathrm{O}_{3}-\mathrm{TiO}_{2}$. Among these four samples, $\mathrm{Bi}_{2} \mathrm{O}_{3}-\mathrm{C} / \mathrm{TiO}_{2}$ exhibited the highest $\mathrm{PL}$ intensity, indicating that $\mathrm{Bi}_{2} \mathrm{O}_{3}-\mathrm{C} / \mathrm{TiO}_{2}$ showed a high recombination rate of photoinduced $\mathrm{e}^{-}$and $\mathrm{h}^{+}$, which was not beneficial to increase the activity for photocatalytic oxidation of $\mathrm{HCHO}$. While, compared with $\mathrm{Bi}_{2} \mathrm{O}_{3}-\mathrm{N} / \mathrm{TiO}_{2}, \mathrm{Bi}^{3+} / \mathrm{TiO}_{2}$ displayed a lower PL intensity, implying that $\mathrm{Bi}^{3+} / \mathrm{TiO}_{2}$ could improve charge separation with a low recombination rate of $\mathrm{e}^{-}$and $\mathrm{h}^{+}$. This was mainly due to the $\mathrm{Bi}^{3+}$ doping on $\mathrm{TiO}_{2}$, which can capture photogenerated $\mathrm{e}^{-}$from the surface of $\mathrm{Bi}_{4} \mathrm{Ti}_{3} \mathrm{O}_{12}$ to reduce charge recombination. This result indicates that $\mathrm{Bi}^{3+} / \mathrm{TiO}_{2}$ can exhibit a higher photocatalytic activity due to that $\mathrm{Bi}^{3+}$ doping $\mathrm{TiO}_{2}$ hinders free carriers from recombination under irradiation. Although $\mathrm{Bi}_{2} \mathrm{O}_{3}-\mathrm{TiO}_{2}$ showed the lowest PL intensity, the photocatalysts of $\mathrm{Bi}_{2} \mathrm{O}_{3}$ composite was not conducive to photocatalytic oxidation of HCHO. The above results show that the critical factor to determine the activity of these photocatalysts was $\mathrm{Bi}^{3+} / \mathrm{TiO}_{2}$ that was composed of $\mathrm{TiO}_{2}$ and $\mathrm{Bi}_{4} \mathrm{Ti}_{3} \mathrm{O}_{12}$, confirmed by XRD.

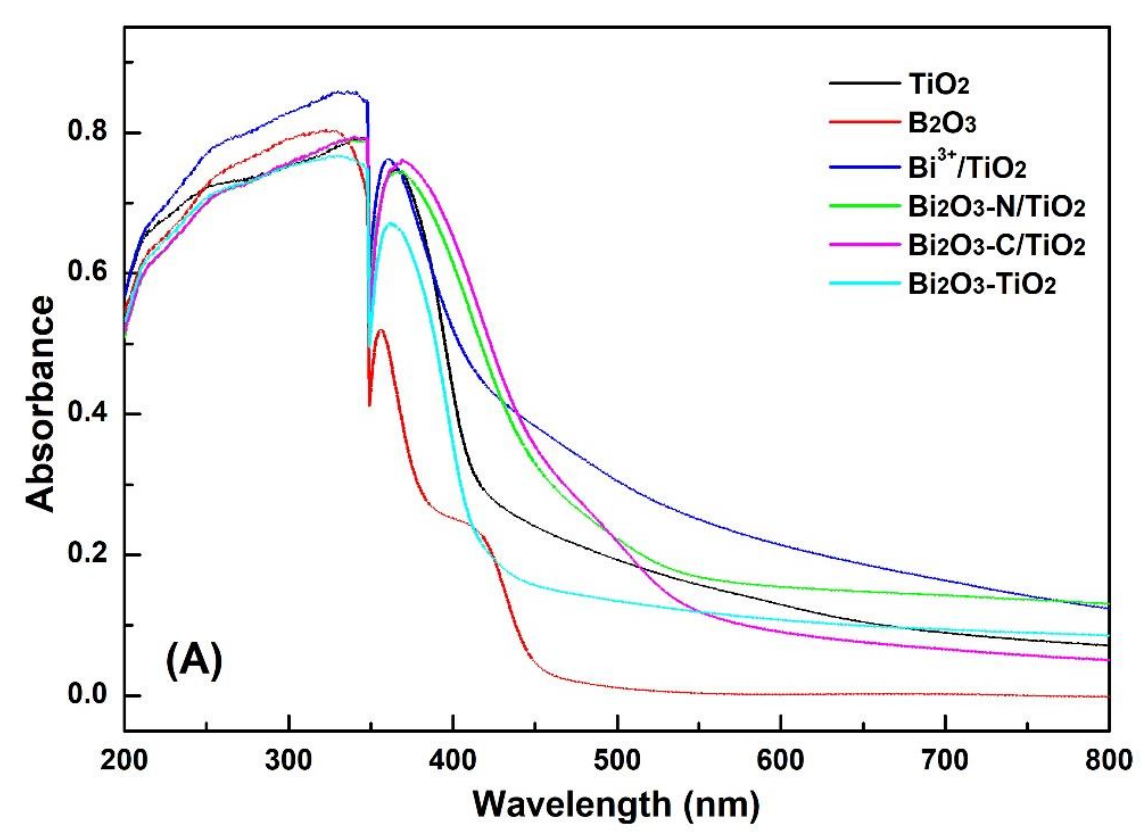




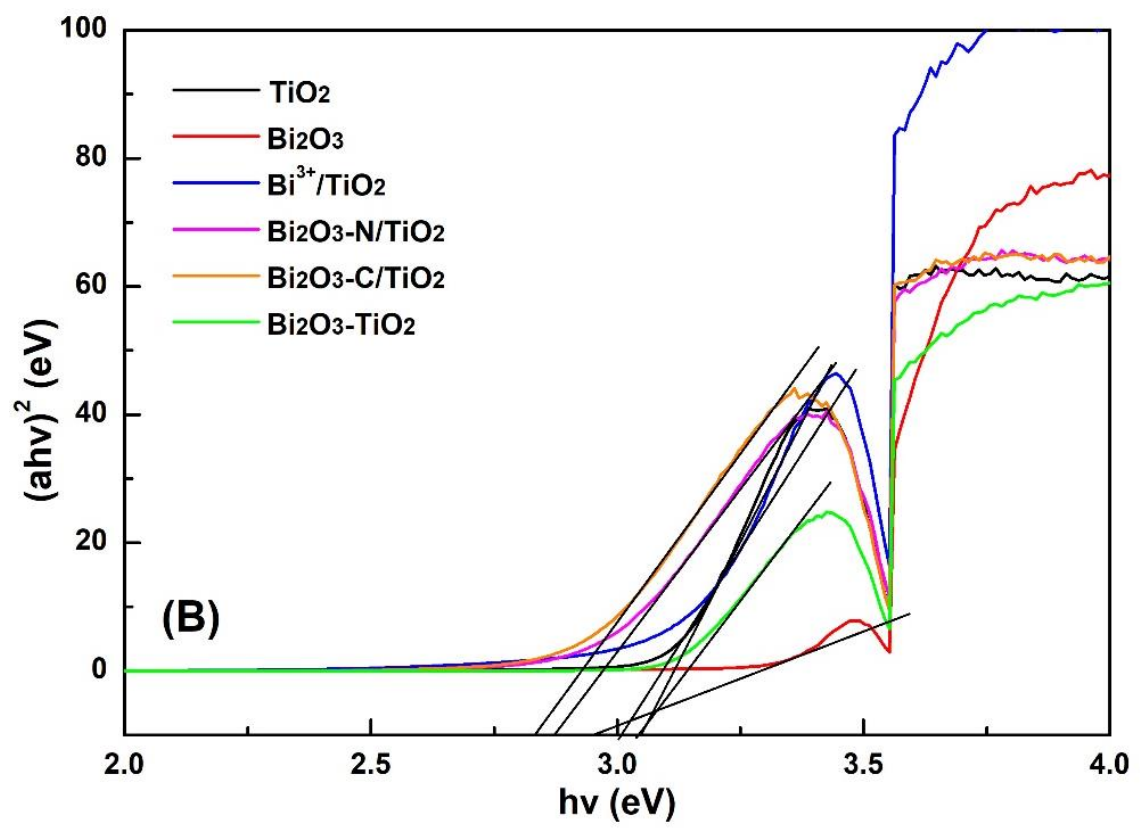

383

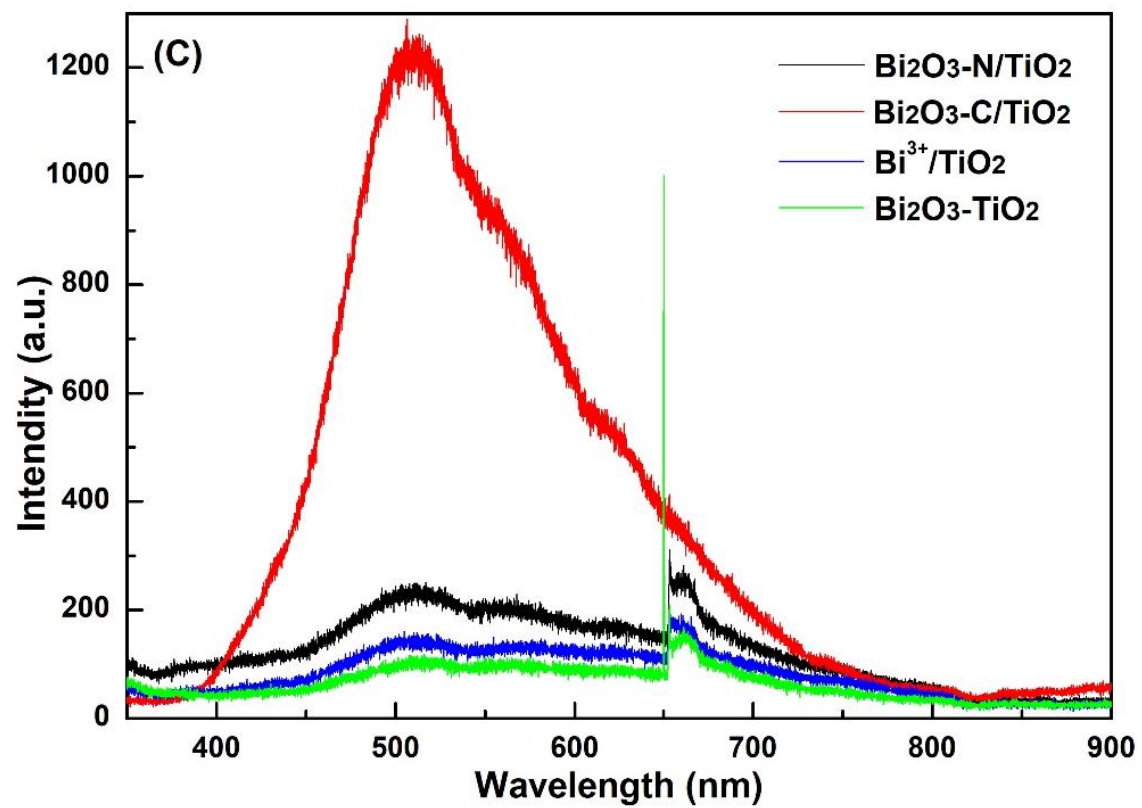



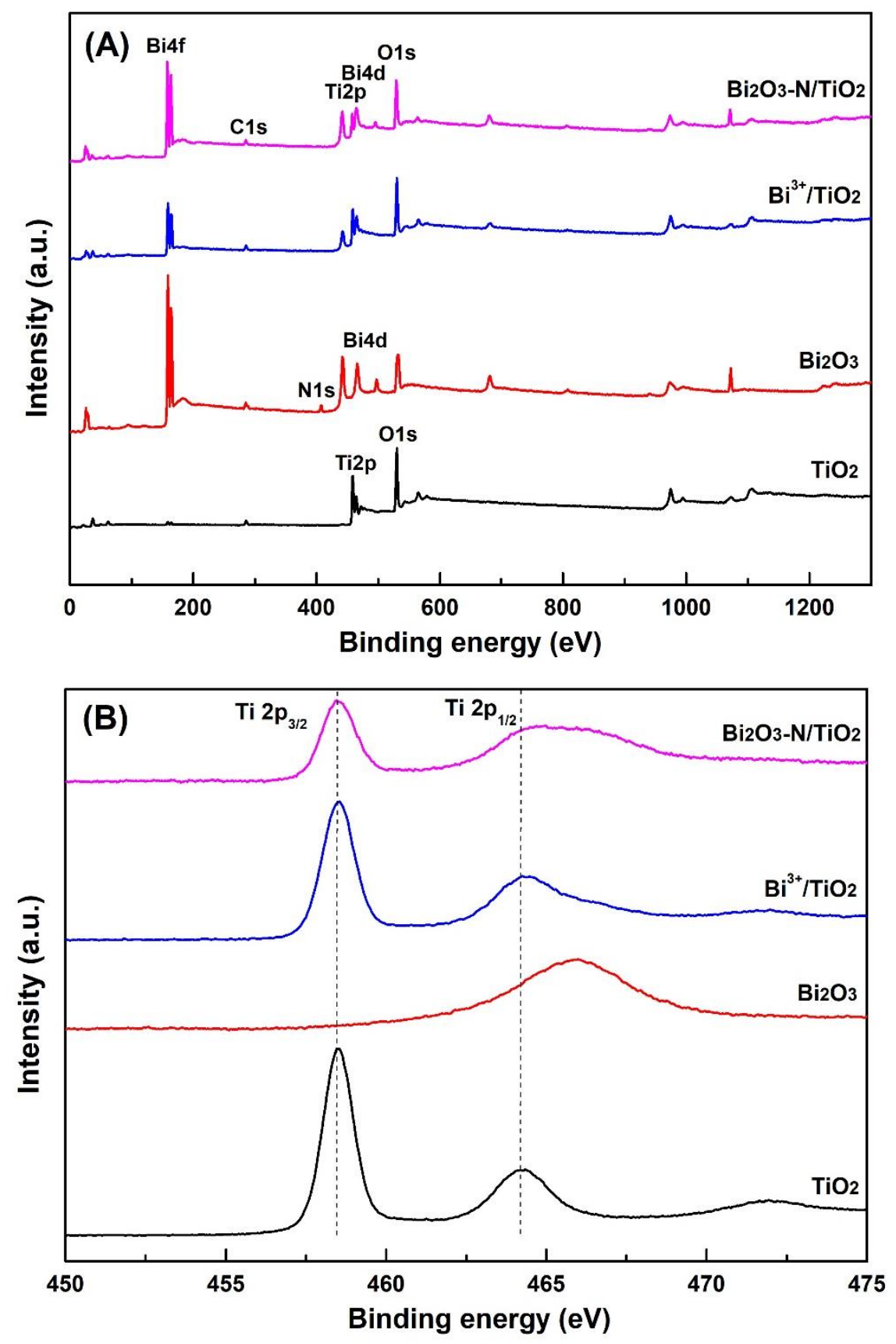

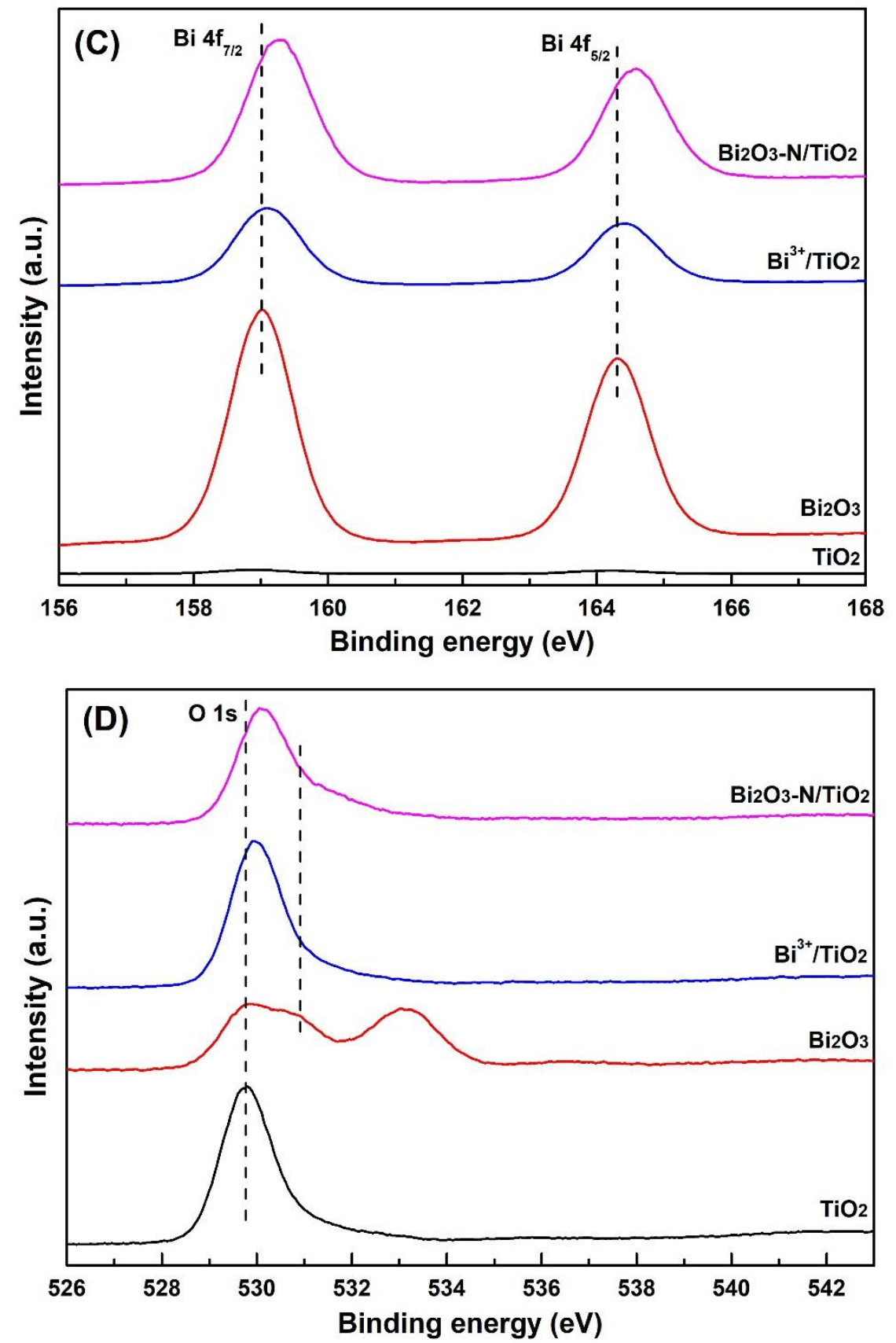

Fig. 7. XPS spectra of different types of $\mathrm{TiO}_{2}, \mathrm{Bi}_{2} \mathrm{O}_{3}$, and $\mathrm{Bi}$-doped $\mathrm{TiO}_{2}$ catalysts

392 The chemical states of $\mathrm{TiO}_{2}, \mathrm{Bi}_{2} \mathrm{O}_{3}$, and $\mathrm{Bi}$-doped $\mathrm{TiO}_{2}$ catalysts were detected by using 393 XPS analysis. Ti, Bi, O, C and $\mathrm{N}$ elements could be observed on the surface of samples 394 (Fig. 7). The Ti $2 \mathrm{p}_{3 / 2}$ and $\mathrm{T} 2 \mathrm{p}_{1 / 2}$ for $\mathrm{TiO}_{2}$ and $\mathrm{Bi}^{3+} / \mathrm{TiO}_{2}$ were situated at a binding energy (BE) of $458.5 \mathrm{eV}$ and $464.2 \mathrm{eV}$, respectively. However, the $\mathrm{BE}$ of $\mathrm{T} 2 \mathrm{p}_{1 / 2}$ for $\mathrm{Bi}_{2} \mathrm{O}_{3}-\mathrm{N} / \mathrm{TiO}_{2}$ was shifted to high binding energy due to the influence of $\mathrm{Bi}_{2} \mathrm{O}_{3}{ }^{[39]}$. The results implied that $\mathrm{Bi}^{3+} / \mathrm{TiO}_{2}$ and $\mathrm{Bi}_{2} \mathrm{O}_{3}-\mathrm{N} / \mathrm{TiO}_{2}$ consisted of $\mathrm{TiO}_{2}$ and $\mathrm{Bi}_{2} \mathrm{O}_{3}$, and these were all consistent with XRD analysis. Interestingly, the $\mathrm{Bi}$ 4f photoelectron peaks of 
Bi-doped $\mathrm{TiO}_{2}$ had a positive shift to a high $\mathrm{BE}$ with pure $\mathrm{Bi}_{2} \mathrm{O}_{3}$, indicating that the introduction of Bi could induce a strong interplay and $\mathrm{e}^{-}$transferred between $\mathrm{TiO}_{2}$ and

$401 \mathrm{Bi}_{2} \mathrm{O}_{3}$ to generate composite oxides $\left(\mathrm{Bi}_{4} \mathrm{Ti}_{3} \mathrm{O}_{12}\right)$. Among them, $\mathrm{Bi}_{2} \mathrm{O}_{3}-\mathrm{N} / \mathrm{TiO}_{2}$ was the 402 most obvious and $\mathrm{Bi}^{3+} / \mathrm{TiO}_{2}$ was the second, and the result was in agreement with UV403 vis and PL spectra. The XPS of the $\mathrm{O} 1 \mathrm{~s}$ were also detected. The $\mathrm{O} 1 \mathrm{~s}$ levels for $\mathrm{TiO}_{2}$ 404 and $\mathrm{Bi}_{2} \mathrm{O}_{3}$ were markedly different and fell to $529.8 \mathrm{eV}$ and $533.1 \mathrm{eV}$, respectively. In 405 general, the $\mathrm{O} 1 \mathrm{~s}$ could be deconvoluted into three contributions ${ }^{[7]}$ : one with the BE of $406529.8-529.3 \mathrm{eV}$ indicated to lattice oxygen $\left(\mathrm{O}_{\mathrm{lat}}\right)$, and the other two with $\mathrm{BE}$ of 531.6407530.8 and 534.3-532.2 eV assigned to surface adsorbed oxygen $\left(\mathrm{O}_{\text {sur }}\right)\left(\mathrm{O}_{2}{ }^{2-}\right.$ or $\left.\mathrm{O}^{-}\right)$and 408 oxygen species, such as $\mathrm{OH}$. The $\mathrm{Bi}^{3+} / \mathrm{TiO}_{2}$ and $\mathrm{Bi}_{2} \mathrm{O}_{3}-\mathrm{N} / \mathrm{TiO}_{2}$ displayed a higher $\mathrm{BE}$ 409 of lattice oxygen, indicating that $\mathrm{e}^{-}$transfer between $\mathrm{TiO}_{2}$ and $\mathrm{Bi}_{2} \mathrm{O}_{3}$. Moreover, the 410 amount of $\mathrm{O}_{\text {sur }}$ could be increased due to $\mathrm{Bi}$ doping. The above measurements indicated 411 the charge transfer between $\mathrm{Ti}, \mathrm{Bi}$ and $\mathrm{O}$ occurring with $\mathrm{Bi}$ doping.

\section{$412 \quad 3.8$ In-situ DRIFTS and IR spectral characteristics}

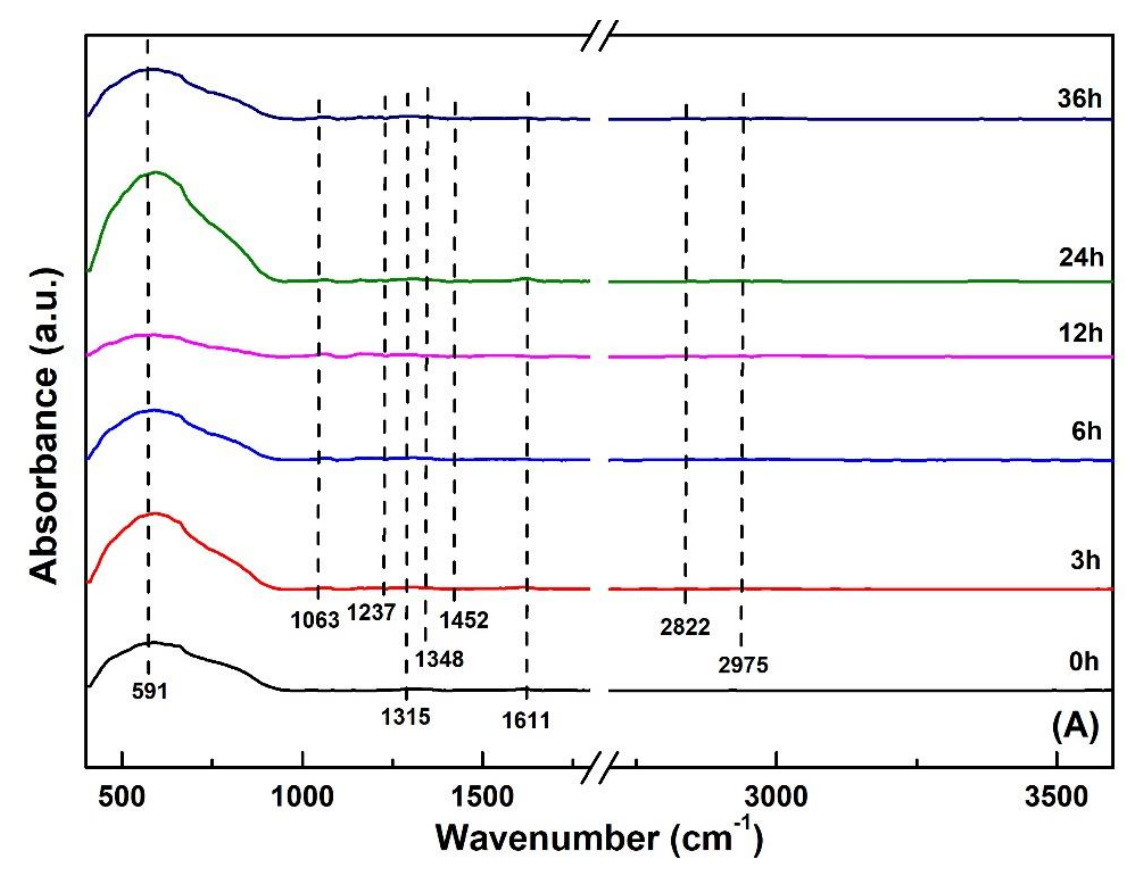



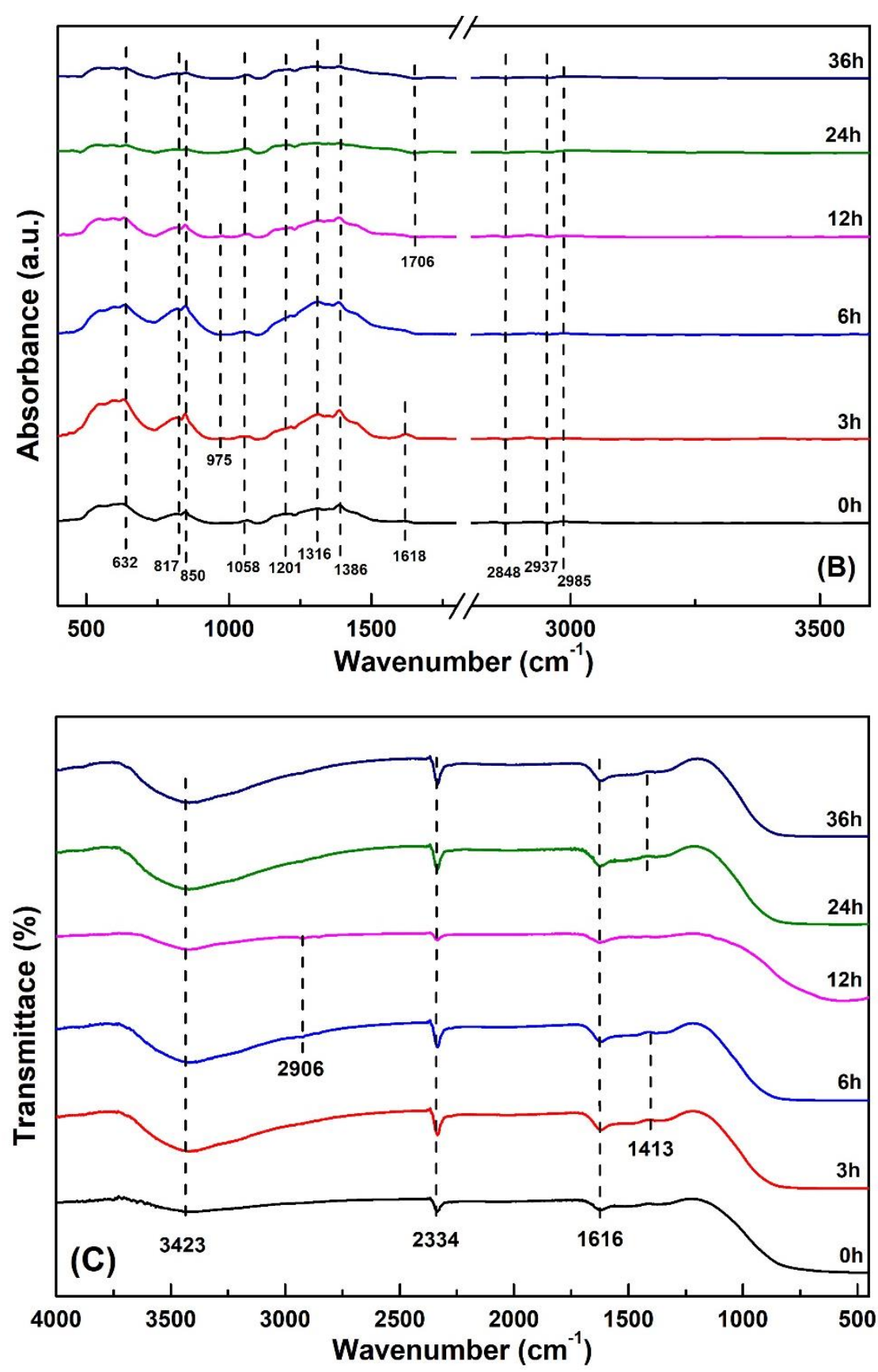


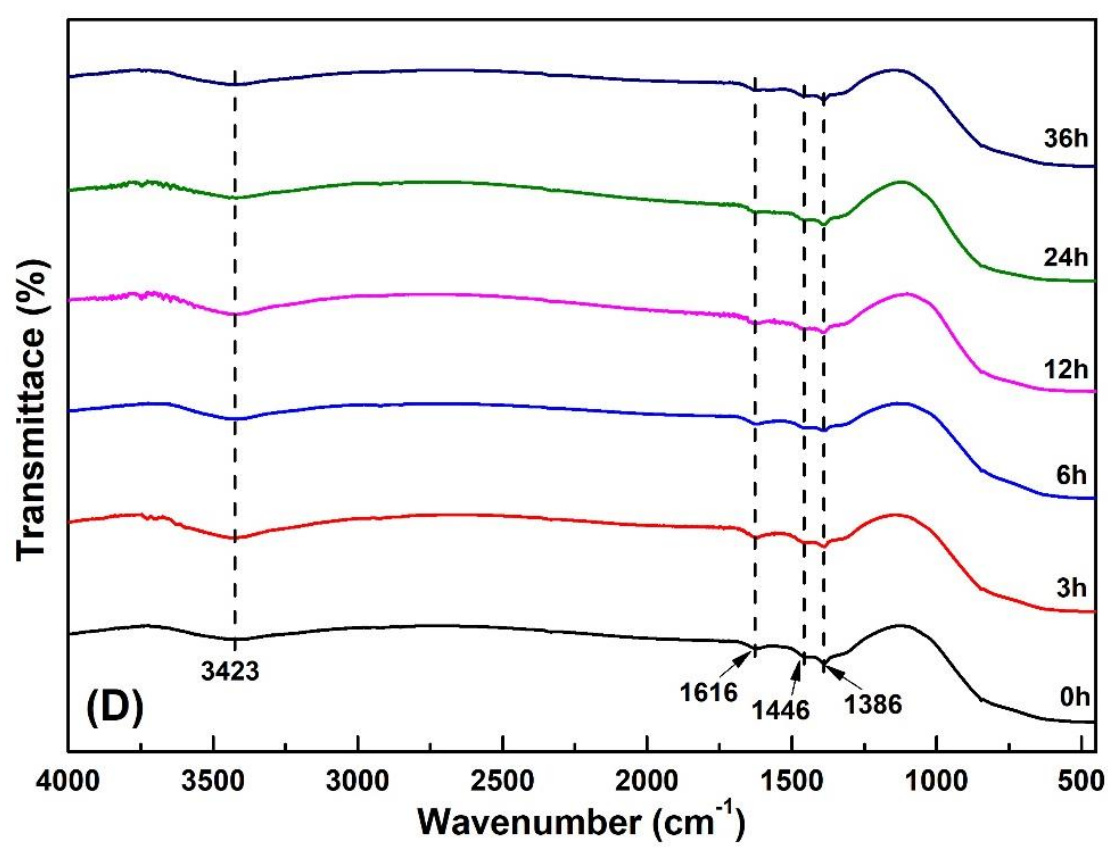

Fig. 8. In-situ DRIFTS and IR spectrum for $(\mathrm{A}, \mathrm{C}) \mathrm{Bi}^{3+} / \mathrm{TiO}_{2}$, and (B, D) $\mathrm{Bi}_{2} \mathrm{O}_{3}-\mathrm{N} / \mathrm{TiO}_{2}$ catalysts with the different reaction time

Base on the In-situ DRIFTS spectra of $\mathrm{Bi}^{3+} / \mathrm{TiO}_{2}$ and $\mathrm{Bi}_{2} \mathrm{O}_{3}-\mathrm{N} / \mathrm{TiO}_{2}$, as shown in Fig. 8A) and Fig. 8(B), upon exposure to a mixed flow of $\mathrm{HCHO} / \mathrm{O}_{2}\left(1.05 \pm 0.05 \mathrm{mg} / \mathrm{m}^{3}\right)$ with different reaction time $(0,3,6,12,24$, and 36h) and different bands, such as 591, $1063,1160,1237,1315 \mathrm{~cm}^{-1}$ and others could be observed. According to references ${ }^{[1,}$ 2, 8, 9, 14, 42], as for $\mathrm{Bi}^{3+} / \mathrm{TiO}_{2}$, the bands at 591 and $1315 \mathrm{~cm}^{-1}$ of $\mathrm{Bi}^{3+} / \mathrm{TiO}_{2}$ can be assigned to the asymmetric stretching vibration of Ti-O-Ti and stretching vibration of Ti-O, respectively ${ }^{[42]}$. The bending vibration of water at ca. $1611 \mathrm{~cm}^{-1}$ and the characteristic bands of molecularly adsorbed $\mathrm{HCHO}$ at $1063 \mathrm{~cm}^{-1}$ were found in the $\mathrm{Bi}^{3+} / \mathrm{TiO}_{2}{ }^{[14]}$. The band at 1348 and weak bands at 2822 and $2975 \mathrm{~cm}^{-1}$ were attributed to the symmetric $v_{\mathrm{s}}(\mathrm{COO})$ and $v_{\mathrm{s}}(\mathrm{CH})$ stretching of formate ${ }^{[1]}$. In addition, a broad negative band at ca. 1237 and $1452 \mathrm{~cm}^{-1}$ were ascribed to $v_{\mathrm{s}}\left(\mathrm{CH}_{2}\right)$ and $\delta\left(\mathrm{CH}_{2}\right)$ vibration of dioxymethylene (DOM) ${ }^{[2]}$. The results implied that formate and DOM species were the main intermediates for photocatalytic oxidation of $\mathrm{HCHO}$. As for $\mathrm{Bi}_{2} \mathrm{O}_{3}-\mathrm{N} / \mathrm{TiO}_{2}$ (Fig. 8(B)), the characteristic bands with different reaction time were almost the same as $\mathrm{Bi}_{2} \mathrm{O}_{3}-\mathrm{N} / \mathrm{TiO}_{2}(0 \mathrm{~h})$ without significant changing. The bending vibration of $\mathrm{H}_{2} \mathrm{O}$ at 1618 $\mathrm{cm}^{-1}$ and the characteristic bands of molecularly adsorbed $\mathrm{HCHO}$ at $1058 \mathrm{~cm}^{-1}$ were also discovered. Meanwhile, the bands at 1386, 2848 and $2985 \mathrm{~cm}^{-1}$ were also ascribed 
to the symmetric $v_{s}(\mathrm{COO})$ and $v_{\mathrm{s}}(\mathrm{CH})$ stretching of formate. With the prolonging reaction time, the band at $1618 \mathrm{~cm}^{-1}$ corresponding to the bending vibration of $\mathrm{OH}^{-}$in water adsorbed decreased and the band at $1710 \mathrm{~cm}^{-1}$ assigned to the $v(\mathrm{CO})$ vibration mode of HCHO emerged.

The analysis of water absorption and surface hydroxyl showed the IR spectrum of $\mathrm{Bi}^{3+} / \mathrm{TiO}_{2}$ and $\mathrm{Bi}_{2} \mathrm{O}_{3}-\mathrm{N} / \mathrm{TiO}_{2}$ (Fig. 8(C) and Fig. 8(D)). The results seemed to no significant of water absorption and surface hydroxyl change with the reaction time. The stretching vibration at ca. $3423 \mathrm{~cm}^{-1}$ corresponded to the hydroxyl group and the bending vibration at ca. $1616 \mathrm{~cm}^{-1}$ was attributed to $\mathrm{OH}$ - from the adsorption of $\mathrm{H}_{2} \mathrm{O}$. However, $\mathrm{Bi}^{3+} / \mathrm{TiO}_{2}$ exhibited markedly higher $\mathrm{H}_{2} \mathrm{O}$ adsorption than $\mathrm{Bi}_{2} \mathrm{O}_{3}-\mathrm{N} / \mathrm{TiO}_{2}$. In addition, the performance of $\mathrm{H}_{2} \mathrm{O}$ adsorption could be increased with reaction time, and thus it displayed a higher activity for $\mathrm{HCHO}$ oxidation. Due to the inadequate photocatalytic oxidation of $\mathrm{HCHO}$ at 3-36h, two absorption bands at ca. $1413 \mathrm{~cm}^{-1}$ and $2906 \mathrm{~cm}^{-1}$ suited to the symmetric or other $\mathrm{C}-\mathrm{H}$ orientations stretching vibration of formate $\left(V_{\mathrm{s}}\left(\mathrm{COO}^{-}\right)\right)$were detected. Furthermore, the bands appearing at around 2334 $\mathrm{cm}^{-1}, 1386 \mathrm{~cm}^{-1}$, and $1446 \mathrm{~cm}^{-1}$ can be assigned to the stretching or bending vibration of C-O $\left(V_{\mathrm{s}}\left(\mathrm{HCO}_{3}{ }^{-}\right)\right)$and $\delta\left(\mathrm{CH}_{2}\right)$ vibration of dioxymethylene (DOM) due to the photocatalytic oxidation reaction. The above results confirmed the presence of surface hydroxyls $\left(\mathrm{OH}^{-}\right)$in the structure of these two samples and revealed that the importance of surface hydroxyls on $\mathrm{HCHO}$ degradation, especially for $\mathrm{Bi}^{3+} / \mathrm{TiO}_{2}$. These adsorbed $\mathrm{H}_{2} \mathrm{O}$ and $\mathrm{OH}^{-}$are crucial to improve the activity for $\mathrm{HCHO}$ oxidation due to their reaction with the photogenerated hole on the surface and the formation of hydroxyl

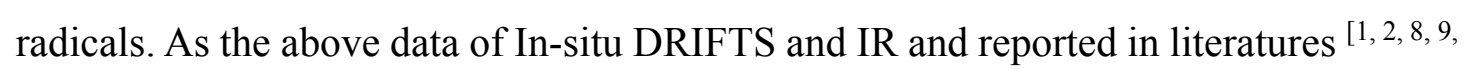
14, 42, 43, 44] HCHO was degraded into dioxymethylene (DOM) at first, and then further into formate and carbonate, then finally desorbs as $\mathrm{CO}_{2}$.

\subsection{EPR spectroscopy}

To understand the roles of reactive oxygen species such as ${ }^{\circ} \mathrm{O}_{2}{ }^{-}$and $\bullet \mathrm{OH}$ in the photocatalytic process, EPR technique was used to detect the characteristics and active radicals in the samples. As shown in Fig. 9, the value of $g=2.003$ was ascribed to the paramagnetic characteristic value of ${ }^{\circ} \mathrm{O}_{2}^{-}{ }^{[45]}$, and the value of paramagnetic 
characteristic could be increased by $\mathrm{Bi}^{3+}$ doping with $\mathrm{TiO}_{2} . \mathrm{Bi}^{3+} / \mathrm{TiO}_{2}$ displayed the highest amount of ${ }^{\bullet} \mathrm{O}_{2}{ }^{-}$, followed by $\mathrm{TiO}_{2}, \mathrm{Bi}_{2} \mathrm{O}_{3}-\mathrm{N} / \mathrm{TiO}_{2}$, and $\mathrm{Bi}_{2} \mathrm{O}_{3}$. The results showed that the types and amount of $\mathrm{Bi}$ doping played an important role in the change of ${ }^{\circ} \mathrm{O}_{2}{ }^{-}$ concentration. When $\mathrm{Bi}_{2} \mathrm{O}_{3}$ doped in $\mathrm{TiO}_{2}$, some of $\mathrm{Bi}_{2} \mathrm{O}_{3}$ exposed as an electrically charged composite centre, which prevented some $\mathrm{e}^{-}$from being trapped by oxygen vacancies. The reduce of charged oxygen vacancies resulted in the reduction of the amount of ${ }^{\circ} \mathrm{O}_{2}{ }^{-[29]}$. Therefore, when the amount of ${ }^{\circ} \mathrm{O}_{2}{ }^{-}$decreased, the peak strength on the paramagnetic characteristic of ${ }^{\circ} \mathrm{O}_{2}{ }^{-}$and the activity decreased, which was consistent with the results of photocatalytic oxidation of $\mathrm{HCHO}$.

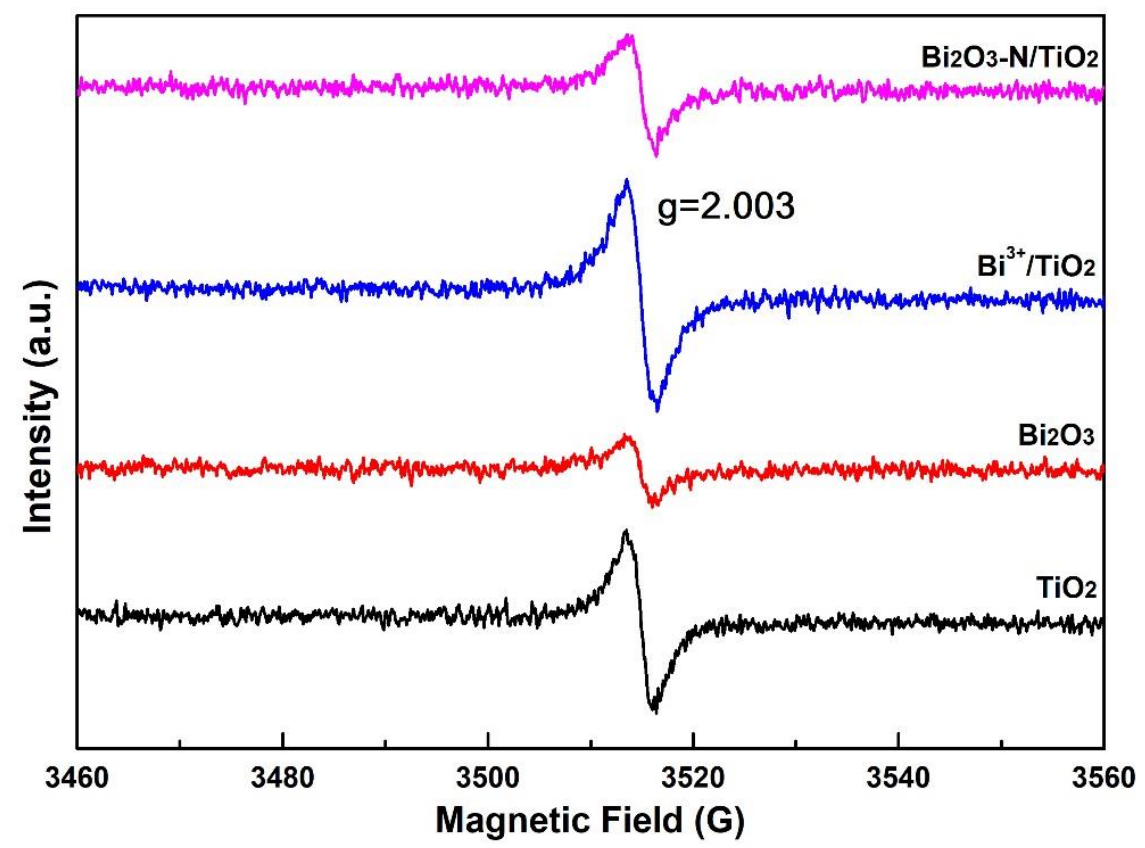

Fig. 9. EPR spectra of different types of $\mathrm{TiO}_{2}, \mathrm{Bi}_{2} \mathrm{O}_{3}$, and $\mathrm{Bi}$-doped $\mathrm{TiO}_{2}$ catalysts

\subsection{Mechanisms for photocatalytic oxidation of $\mathrm{HCHO}$}

Depending on the structure of $\mathrm{Bi}$-doped $\mathrm{TiO}_{2}$, particularly for $\mathrm{Bi}^{3+} / \mathrm{TiO}_{2}$, the structure of heterojunction, identified as $\mathrm{Bi}_{4} \mathrm{Ti}_{3} \mathrm{O}_{4}$ and $\mathrm{TiO}_{2}$, could promote efficient charge separation, with the consequence of reducing the recombination of photogenerated $\mathrm{e}^{-}$ and $\mathrm{h}^{+}$(Fig. 10). Gan et al. found UV-vis DRS, the $E_{b g}$ for $\mathrm{Bi}_{4} \mathrm{Ti}_{3} \mathrm{O}_{4}$ and $\mathrm{TiO}_{2}$ were about $2.91 \mathrm{eV}$ and $3.1 \mathrm{eV}{ }^{[46]}$. Therefore, the $E_{c b}$ and $E_{v b}$ for $\mathrm{Bi}_{4} \mathrm{Ti}_{3} \mathrm{O}_{4}$ and $\mathrm{TiO}_{2}$ were calculated as $-0.41 \mathrm{eV},-0.12 \mathrm{eV}, 2.50 \mathrm{eV}$ and $2.98 \mathrm{eV}$, respectively. Because the $E_{c b}$ of $\mathrm{TiO}_{2}$ was lower than $\mathrm{Bi}_{4} \mathrm{Ti}_{3} \mathrm{O}_{4}$, the photogenerated $\mathrm{e}^{-}$could be moved easily from $\mathrm{Bi}_{4} \mathrm{Ti}_{3} \mathrm{O}_{4}$ to $\mathrm{TiO}_{2}$. The holes transferred in the opposite direction and thus depressed the 
recombination of $\mathrm{e}^{-}$and $\mathrm{h}^{+}$. Moreover, the formation of formate species (2822 and 2975 $\mathrm{cm}^{-1}$ ) and dioxymethylene (1237 and $\left.1452 \mathrm{~cm}^{-1}\right)$, ascribed to the results of in-situ DRIFTS spectra, could be found clearly in the $\mathrm{Bi}^{3+} / \mathrm{TiO}_{2}$. These two kinds of species, identified as by-products of photocatalytic oxidation, could also be observed by IR spectrum. On the other hand, the weak band at $1710 \mathrm{~cm}^{-1}$ corresponding to the $v(\mathrm{CO})$ vibration of $\mathrm{HCHO}$ could be observed on the surface of catalysts. More importantly, the intensity of stretching vibration at ca. $3423 \mathrm{~cm}^{-1}$ assigned to the hydroxyl group decreased with the extension of reaction time.

According to the above investigations, the adsorption of $\mathrm{HCHO}$ on the surface was the first step in the catalytic reaction. $\mathrm{Bi}^{3+} / \mathrm{TiO}_{2}$ was activated by the visible light and the photogenerated $\mathrm{e}^{-}$and $\mathrm{h}^{+}$could be transferred by the heterojunction structure. Then, these $\mathrm{e}^{-}$can react with $\mathrm{O}_{2}$ to generate superoxide radical anion $\left({ }^{\circ} \mathrm{O}_{2}{ }^{-}\right)$, which can oxidize $\mathrm{HCHO}$ into the DOM and formate species. The formate can further break up into CO and $\mathrm{H}_{2} \mathrm{O}$, and $\mathrm{CO}$ could be further oxidized to $\mathrm{CO}_{2}{ }^{[2,47]}$. Another possible pathway is that these photogenerated holes can be combined with $\mathrm{OH}^{-}$or $\mathrm{H}_{2} \mathrm{O}$ to generate hydroxyl radical $(\cdot \mathrm{OH})$, which could directly oxidize $\mathrm{HCHO}$ or formate into $\mathrm{CO}_{2}$ and $\mathrm{H}_{2} \mathrm{O}$ and tackle the environmental pollution $[48,49]$.

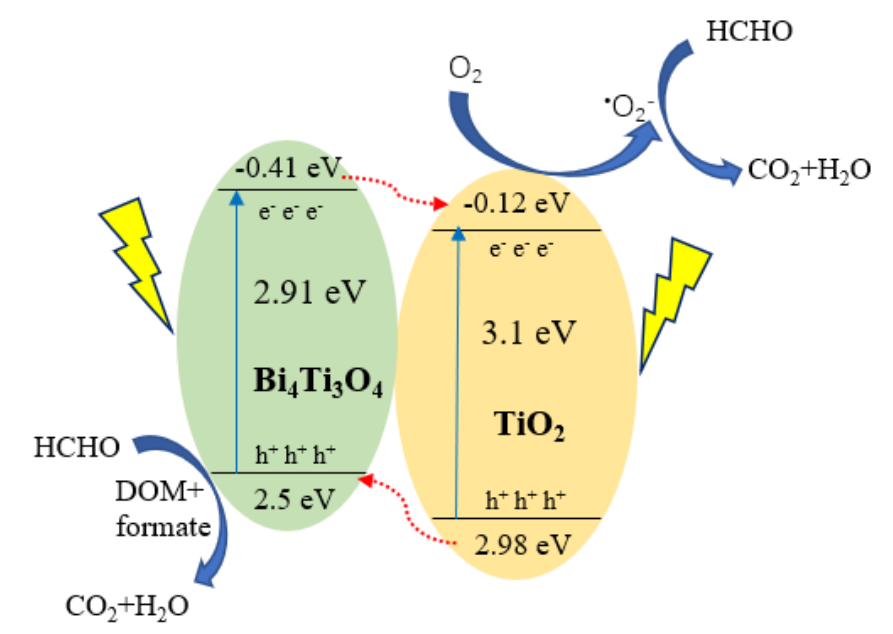

Fig. 10. Proposed electron-hole pair separation in the $\mathrm{Bi}^{3+} / \mathrm{TiO}_{2}$ composites under visible irradiation

\section{Conclusions}

In this study, a serious of $\mathrm{Bi}-$ doped $\mathrm{TiO}_{2}$ catalysts were synthesized by sol using the hydrothermal method, and then promoted for the photocatalytic degradation of $\mathrm{HCHO}$ 
under visible light irradiation and ambient temperature. Compared with pure $\mathrm{TiO}_{2}$ and $\mathrm{Bi}_{2} \mathrm{O}_{3}$, photocatalytic oxidation of $\mathrm{HCHO}$ can be further improved by the Bi-doped $\mathrm{TiO}_{2}$ catalysts, especially $\mathrm{Bi}^{3+} / \mathrm{TiO}_{2}$. According to the investigation of characterization, it could be observed that the excess $\mathrm{Bi}_{2} \mathrm{O}_{3}$ doping into $\mathrm{TiO}_{2}$ catalysts, such as $\mathrm{Bi}_{2} \mathrm{O}_{3}-$ $\mathrm{N} / \mathrm{TiO}_{2}$ and $\mathrm{Bi}_{2} \mathrm{O}_{3}-\mathrm{C} / \mathrm{TiO}_{2}$, formed a mixed oxides with $\mathrm{Bi}_{2} \mathrm{O}_{3}$ and $\mathrm{Bi}_{4} \mathrm{Ti}_{3} \mathrm{O}_{12}$, and they were disadvantage to enhance the activity. However, $\mathrm{Bi}^{3+} / \mathrm{TiO}_{2}$ composed of $\mathrm{TiO}_{2}$ and $\mathrm{Bi}_{4} \mathrm{Ti}_{3} \mathrm{O}_{12}$ displayed a higher activity and remained good stability for $\mathrm{HCHO}$ oxidation. It was worth mention that $\mathrm{Bi}^{3+} / \mathrm{TiO}_{2}$ didn't have the lowest binding energy, but it displayed a lower PL intensity. The highest activity mainly depends on the uniform particulates, high surface areas, and the great interaction between $\mathrm{TiO}_{2}$ and $\mathrm{Bi}_{4} \mathrm{Ti}_{3} \mathrm{O}_{12}$ via charge transfer.

In summary, this study demonstrated that $\mathrm{HCHO}$ can be effectively oxidized to 0.058 $\mathrm{mg} / \mathrm{m}^{3}(94.7 \%)$ at visible light excitation within $36 \mathrm{~h}$. The heterogeneous catalysts with $\mathrm{TiO}_{2}$ and $\mathrm{Bi}_{4} \mathrm{Ti}_{3} \mathrm{O}_{12}$ were the main critical factor to degrade gaseous organic pollutants. The results made new contribution for a better understanding of the existing state of $\mathrm{Bi}$ in the $\mathrm{TiO}_{2}$ crystal.

\section{Acknowledgements}

This work was financially supported by the Natural Science Foundation of Jiangsu Province (Nos. BK20170954 and BK20150890), the National Natural Science Foundation of China (Nos. 21501097), the Qing Lan Project of the Jiangsu Higher Education Institutions of China, the Priority Academic Program Development of Jiangsu Higher Education Institutions (PAPD), the Top-notch Academic Programs Project of Jiangsu Higher Education Institutions (PPZY2015C222), the Jiangsu Engineering Technology Research Centre of Environmental Cleaning Materials and Open Research Fund Program of Jiangsu Key Laboratory of Atmospheric Environment Monitoring \& Pollution Control (KHK1806), A projected funded by the Priority Academic Program Development of Jiangsu Higher Education Institutions (PAPD). 


\section{References}

[1] F. Liu, S.P. Rong, P.Y. Zhang, L.L. Gao. Appl. Catal. B 235 (2018) 158.

[2] D. Sun, S. Wageh, A.A. Al-Ghamdi, Y. Le, J.G. Yu, C.J. Jiang. Appl. Surf. Sci. 466 (2019) 301. [3]V. Binas, V. Stefanopoulos, G. Kiriakidis, P. Papagiannakopoulos. J. Mater. 5 (2019) 56.

[4] A. Okawa, R. Yoshida, T. Isozaki, Y. Shigesato, Y. Matsushita, T. Suzuki. Catal. Commun. 100 (2017) 1.

[5] X.A. Dong, W. Cui, H. Wang, J.Y. Li, Y.J. Sun, H.Q. Wang, Y.X. Zhang, H.W. Huang, F. Dong. Sci. Bull. 64 (2019) 669.

[6] J.Y. Li, X.A. Dong, G. Zhang, W. Cui, W.L. Cen, Z.B. Wu, S. C. Lee, F. Dong. J. Mater. Chem. A 7 (2019) 3366.

[7] Z. Zhang, J. Huang, H.Q. Xia, Q.G. Dai, Y.F. Gu, Y.J. Lao, X.Y. Wang. J. Catal. 360 (2018) 277.

[8] Z.X. Yan, Z.H. Xu, Z.H. Yang, L. Yue, L.Y. Huang. Appl. Surf. Sci. 467 (2019) 277.

[9] Y. Zhang, M.X. Chen, Z.X. Zhang, Z. Jiang, W.F. Shangguan, H. Einaga. Catal. Today. 327 (2019) 323.

[10] D. Kibanova, M. Sleiman, J. Cervini-Silva, H. Destaillats. J. Hazard. Mater. 211 (2012) 233.

[11] X.Q. Deng, J.L. Liu, X.S. Li, B. Zhu, X.B. Zhu, A.M. Zhu. Catal. Today. 281 (2017) 630.

[12] J.Y. Li, W. Cui, P. Chen, X.A. Dong, Y.H. Chu, J.P. Sheng, Y.X. Zhang, Z.M. Wang, F. Dong. Appl. Catal. B 260 (2020) 118130.

[13] X.S. Li, X.Y. Ma, J.L. Liu, Z.G. Sun, B. Zhu, A.M. Zhu. Catal. Today. 337 (2019) 132.

[14] S.Y. Huang, B. Cheng, J.G. Yu, C.J. Jiang. ACS Sustain. Chem. Eng. 6 (2018) 12481.

[15] G.K. Zhang, Q. Xiong, W. Xu, S. Guo. Appl. Clay. Sci. 102 (2014) 231.

[16] M. Malayeri, F. Haghighat, C.S. Lee. Build. Environ. 154 (2019) 309.

[17] G.X. Zhang, Z.M. Sun, Y.W. Duan, R.X. Ma, S.L. Zheng. Appl. Surf. Sci. 412 (2017) 105.

[18] X. Li, X.R. Qian, X.H. An, J.W. Huang. Appl. Surf. Sci. 487 (2019) 1262.

[19] R.F. Liu, W.B. Li, A.Y. Peng. Appl. Surf. Sci. 427 (2018) 608.

[20] M. He, J. Ji, B.Y. Liu, H.B. Huang. Appl. Surf. Sci. 473 (2019) 934.

[21] T. Ohno, M. Akiyoshi, T. Umebayashi,K. Asai, T. Mitsui, M. Matsumura. Appl. Catal. A 265 (2004) 115.

[22] X.Y. Pan, Y.J Xu. J. Phys. Chem. C. 117 (2013) 17996.

[23] J. Li, M. Zhang, Q.Y. Li, J.J. Yang. Appl. Surf. Sci. 391 (2017) 184.

[24] C. Huang, Y. Ding, Y.W. Chen, P. Li, S.B. Shen. J. Environ. Sci. 60 (2017) 61.

[25] S.H. Liu, W.X. Lin. J. Photoch. Photobio. A 378 (2019) 66.

[26] W. Low, V. Boonamnuayvitaya. J. Environ. Manage. 127 (2013) 142.

[27] J.P. Li, D.J. Ren, Z.X. Wu, J. Xu, Y.J. Bao, S. He, Y.H. Chen. J. Colloid. Inter. Sci. 530 (2018) 78. 
573 [28] Q. Huang, P. Wang, Y.Z. Fan, Q. Wang. Indoor. Built. Enviro. 26 (2017) 785.

574 [29] Y.F. Huang, Y.L. Wei, J. Wang, D. Luo, L.Q. Fan, J.H. Wu. Appl. Surf. Sci. 423 (2017) 119.

575 [30] Y.B. Liu, G.Q. Zhu, J.Z. Gao, M. Hojamberdiev, R.L. Zhu, X.M. Wei, Q.M. Guo, P. Liu. Appl. $576 \quad$ Catal. B $200(2017) 72$.

577 [31] S. Murcia-López, M. Hidalgo, J.A. Navío. Appl. Catal. A 404 (2011) 59.

578 [32] B. Benalioua, M. Mansour, A. Bentouami, B. Boury, E.H. Elandaloussi. J. Hazard. Mater. 288 $579 \quad$ (2015) 158.

580 [33] A. Hamdi, A.M. Ferraria, A.M. Botelho Rego, D.P. Conceicao, L.F. Vieira Ferreira, S. Bouattour. J. Mol. Catal. A 380 (2013) 34.

582

[34] L.W. Lu, M.L Lv, D. Wang, G.Liu, X.X. Xu. Appl. Catal. B 200 (2017) 412.

583 [35] J.H. Lee, H. Lee, M.J. Kang. Mater. Lett. 178 (2016) 316.

584 [36] J. Zhu, S.H. Wang, J.G. Wang, D.Q. Zhang. Appl. Catal. B 102 (2011) 120.

585 [37] C.C. Pei, W.W.F. Leung. Appl. Catal. B 174 (2015) 515.

586 [38] J.Z. Wang, H.L. Li, X.R. Yan, C. Qian, Y.J. Xing, S.T. Yang, Z.K. Kang, J.Y. Han, W.X. Gu, 587 H.Y. Yang, F.J. Xiao. J. Alloys. Compounds. 795 (2019) 120.

[39] Y. Hu, Y.T. Cao, P.X. Wang, D.Z. Li, W. Chen, Y.H. He, X.Z. Fu, Y. Shao, Y. Zhang. Appl. Catal. B 125 (2012) 294.

[40] T.V.L. Thejaswini, D. Prabhakaran, M.A. Maheswari. J. Environ. Chem. Eng. 4 (2016) 1308.

[41] Q. Huang, Q. Wang, T. Tao, Y.X. Zhao, P. Wang, Z.Y. Ding, M.D. Chen. Environ. Technol. 40 (2019) 1937.

[42] H.S. Zuo, J. Sun, K.J. Deng, R. Su. Chem. Eng. Technol. 30 (2007) 577.

[43]P. Liu, G.L. Wei, H.P. He, X.L. Liang, H.L. Chen, Y.F. Xi, J.X. Zhu. Appl. Surf. Sci. 464 (2019) 287.

[44] P. Liu, G.L. Wei, X.L. Liang, D. Chen, H.P. He, T.H. Chen, Y.F. Xi, H.L. Chen, D.H. Han, J.X. Zhu. Appl. Clay. Sci. 161 (2018) 265.

[45] C.P. Kumar, N.O. Gopal, T.C. Wang, M.S. Wong, S.C. Ke. J. Phy. Chem. B 110 (2006) 5223.

[46] H.H. Gan, F.T. Yi, H.N. Zhang, Y.X. Qian, H.X. Jin, K.F. Zhang. Chinese. J. Chem. Eng. 26 (2018) 2628.

[47] Y. Ma, G.K. Zhang. Chem. Eng. J. 288 (2016) 70.

603

[48]. H. Yang, X. Huang, J.R. Thompson, R.J. Flower. Science 347 (2015) 834.

[49]. H. Yang. Nature 509 (2014) 535. 